\title{
Implications of General Systems Theory for Librarianship and Higher Education
}

\begin{abstract}
Systems science has both theoretical and empirical dimensions. General systems theory investigates the isomorphism of concepts, laws, and models in the various domains of human inquiry. General systems theory has implications for both academic librarianship and the teaching-learning process in higher education. With respect to the former, it promotes the conceptual reorganization of knowledge for storage and retrieval. With regard to the latter, it seeks to identify concepts whose organizing power transcends the artificial bounds of the academic disciplines.
\end{abstract}

D URING the first quarter of the nineteenth century, American higher education was attacked by those who deplored its theological orthodoxy and smug classicism. In defense of the existing order and in an attempt to define what the American college ought to be, the faculty of Yale College issued its famous (or, depending upon one's point of view, infamous) report of 1828. The goals of liberal education were stated early in the report: "The two great points to be gained in intellectual culture, are the discipline and the furniture of the mind; expanding its powers and storing it with knowledge."1 Set in a mid-twentiethcentury context, these educational prescriptions do not seem entirely irrelevant despite their defensive posture at the time of enunciation. In the 137 years since the issuance of the report, there has

${ }^{x}$ Quoted in Frederick Rudolph, The American College and University: A History (New York: Knopf, 1962), p. 132. The Yale Report of 1828 was published as "Original Papers in Relation to a Course of Liberal Education," The American Journal of Science and Arts, XV (1829), 297-351. It also appeared in Reports on the Course of Instruction in Yale College: by a Committee of the Corporation and the Academical Faculty (New Haven [1828]).

Mr. Bergen is Chairman and Associate Professor, Department of Library Science, University of Mississippi. seemed to develop, the countervailing efforts of this century notwithstanding, an imbalance in American higher education in favor of one of its two emphases. Concerned with furnishing student minds with knowledge, mainly knowledge of a low order of abstraction, American institutions of higher education have by and large underemphasized the goal of discipline, that is to say, the task of acquainting students with the means by which the knowledge they have been furnished may be ordered and made meaningful. It is precisely in this realm of discipline, or, put another way, in the imaginative organization of knowledge for transmission from one generation to the next, that the major implications of general systems theory for librarianship and higher education seem to lie. Only to the extent that these implications are realized can Kenneth Boulding's suggestion of a reorientation in educational thinking-from the existing norm of maximum knowledge transmission to a new and more relevant norm of minimum knowledge transmissionbe accomplished. ${ }^{2}$ It is to that very large

\footnotetext{
${ }^{2}$ See Boulding, The Image: Knowledge in Life and Society (Ann Arbor: Univ. of Michigan Pr., 1956), pp. 162-63.
} 
end that this very modest paper seeks to contribute.

The processes underlying the growth of human knowledge are undoubtedly very complex. The very complexity of these processes should not, however, deter a search for pattern and order in them. One way of viewing the growth of knowledge historically is through the alternating dominance of raw empiricism and low order empirical theory on one hand, and speculative philosophy and logically and mathematically informed hypothetico-deductive theory on the other. To interpret the development of knowledge within such a cyclic framework is to see its growth in terms of the dominant strategies employed over time in its generation. For example, the speculative philosophy of the late medieval period can be depicted as hovering above, in its abstractness and formalism, the seeming disorder of the empirical world much like a hovercraft hovers directly above a point on land or water without ever settling on it. The intellectual formulations of the fourteenth century have been characterized as "verbal, logic-chopping, and abstract" as a consequence of their obsession with "discipline, method, and artifice." In contrast, a medieval schoolman reincarnated during the last quarter of the nineteenth century might well have deplored the excessive empiricism of the emergent academic specialties and their emphasis on "subject matter, experience, and nature," not to mention their inclination toward the "factual, pragmatic, and technical." ${ }^{3}$

\footnotetext{
s'Richard P. McKeon, "The Liberating Arts and the Humanizing Arts in Education," in Arthur A. Cohen (ed.), Humanistic Education and Western Civilization: Essays for Robert M. Hutchins (New York: Holt, Rinehart and Winston, 1964, pp. 169-70. A modern analogue of the postulates of speculative philosophy are the mathematically formulated deductive postulates of theoretical physics which tend to be judged more on a basis of aesthetic excellence than on any criterion of empirical validation. See Peter Caws, The Philosophy of Science: A Systematic Account (Princeton, N.J.: Van Nostrand, 1965), pp. 283-84.
}

Peter Caws has interpreted the progression of science as a continuing dialectic or interplay between its logical and experimental aspects, the former involving "the rational investigation of connections between concepts, without special regard to the adequacy of the concepts to experience" and the latter "the empirical investigation of connections between events, without special regard to the significance of these events in any total scheme of things." ${ }^{4}$ The relationship between logical construction and empirical investigation in the development of knowledge viewed both holistically and in its man-defined subdivisions seems indeed to be reflected in a mutual feedback which drives the structure of knowledge, over the long term, toward a kind of homeostatic steady state. It has been suggested that the output of empirical knowledge in the various academic disciplines (and therefore, by extension, in knowledge as a whole) is controlled by the differential integrative capacities of those disciplines. ${ }^{5}$ Thus it follows that where a discipline's logical or theoretic-deductive component is well developed the production of empirical knowledge will be facilitated. This hypothesis also suggests, at least for the modern intellectual disciplines, that any imbalance between theoretic and empiric dimensions is ultimately corrected by the internal logic of equilibrium. Still, over the short term, the empiric is capable of outrunning the theoretic and vice versa. From the standpoint of organizing knowledge for transmission, the seriousness of theoretical knowledge outdistancing empirical knowledge is not so great as that of empirical investigation outrunning integra-

\footnotetext{
Caws, op. cit., p. 331.

"See Norman W. Storer and Talcott Parsons, "The Disciplines as a Differentiating Force," in Dan Bergen (ed.), The Foundations of Access to Knowledge (Syracuse, N.Y.: School of Library Science, Syracuse University, in Press), (pp. 23-24 in the mimeographed form).
} 
tive capacity. ${ }^{6}$ It is this latter type of imbalance that can lead to the crisis of a civilization incapable of meaningfully integrating its knowledge. To counter such imbalance would seem to be a most worthy rationale for general systems theory.

In an anthropomorphic sense, the growth of knowledge may be viewed in evolutionary perspective as a process of progressive differentiation of the total domain of inquiry. Even though philosophy embodied the bulk of human knowledge from the classical Greek period to the eighteenth century, some differentiation could already be observed during medieval times. If the grammar, rhetoric, and logic of the trivium were not strictly subjective matters, the remaining liberal arts of the quadrivium (arithmetic, geometry, astronomy, and music) had the character of nascent academic disciplines. ${ }^{7}$ There were also, in the medieval universities, separate faculties of law, theology, and medicine. By the early eighteenth century, philosophy itself had developed two identifiable branchesmoral philosophy, which remained largely speculative and normative in character, and natural philosophy, which was scientific mainly in the enumerative or taxonomic sense of that term. The modern scientific disciplines did not evolve out of natural philosophy until well into the nineteenth century. It is widely held, at the present time that the individual disciplines of the physical, biological, and social sciences are distinguished from one another by the different objects

\footnotetext{
- Caws, op. cit., pp. 331-34. Karl W. Deutsch has discerned that the interplay between the empiricalinductive and theoretical-deductive components in science define a continuum along which the different disciplines may be located in terms of the relative importance of these two dimensions within them. See his "Scientific and Humanistic Knowledge in the Growth of Civilization," in Harcourt Brown (ed.), Science and the Creative Spirit: Essays on the Humanistic Aspects of Science (Toronto: Univ, of Toronto $\operatorname{Pr}$., 1958), p. 8.

'McKeon in Cohen (ed.), op. cit., p. 165.
}

and events which they seek to explain. ${ }^{8}$ Russell Ackoff has observed, however, that the intellectual disciplines are simply a reflection of man's effort to organize nature and not necessarily therefore reflective of the inherent structure of nature. Academic disciplines, as a consequence, are differentiated less on the basis of unique subject matters than on a determination of their attention to different aspects of reality and by the various ways in which they explain the same phenomena. ${ }^{9}$ This distinction is important since it calls into question the existence of a correspondence between the structure of knowledge as embodied in the disciplines, and the structure of nature. This difference will be discussed in greater detail later in the paper when the distinction between conceptual and concrete systems is considered.

It has been intimated above that the development of individual disciplines, indeed the growth of knowledge as a whole, may be viewed cybernetically as the interplay or mutual feedback of theoretical and empirical components. Saul Gorn has conceptualized this process in terms of information storage and retrieval using file growth as an analogy:

What happens is that there must be a balance, as the file grows, between the retrievability of the information and the needed communication flow of the information; the control of the information due to the structure of its arrangement must balance the method by which it is communicated. What has happened, then, is that the continuum of a domain of knowledge when a revolution is due, either splits into distinct fields or changes phase radically by a change in the structure of its arrangement. That is,

\footnotetext{
This is one of the criteria specified by Caws, op. cit., p. 280. This criterion for the differentiation of disciplines is shared by Marc Belth. See his Education as a Discipline: A Study of the Role of Models in Thinking (Boston: Allyn and Bacon, 1965), p. 6.

- See Russell L. Ackoff, Scientific Method: Optimizing Applied Research Decisions (New York: Wiley, 1962 ), p. 419 .
} 
once the mass of information got beyond the critical mass, usually either fission or fusion occurred. Fusion is the change in the structure of the individual science itself to make it a much more compact carrier of information; for example, general laws are highly compact bouillon cubes of information. Fission is the breaking up into various areas of specialization, which we have already mentioned. The fission or fusion occurred in each case because the information got beyond our capacity, and its former control began to require too much time to retrieve. In order to be able to retrieve the information, you either have to have separate specialized lumps or have a violent change in structure. ${ }^{10}$

Viewed macroscopically from the standpoint of knowledge as a whole the discrete disciplines yielded by man-directed fission can be re-fused through the imposition of man-inspired constructs which correlate, in some meaningful way, the empirically validated principles of the various academic disciplines. Viewed microscopically, from the standpoint of a particular discipline, the hegemony of either fission or fusion is dependent in very large measure upon that discipline's stage of development. The thrust of fission is strongest during a discipline's initial or taxonomic stage of growth. This first stage of inquiry, called by F. S. C. Northrop the "natural history" stage, is concerned with classification "whether dealing with pure compounds in chemistry, minerals in geology, species in botany, structures in anatomy, or specific functions in physiology."11 The second level of a discipline's development is that of empirically-based theory, what Caws has called the nomo-

${ }^{10}$ Saul Gorn, "Computers, Communications, and Science-Extending Man's Intellect," in Lowell H. Hattery and Edward M. McCormick (eds.), Information Retrieval Management (Detroit: American Data Processing, 1962), p. 126.

in. W. Gerard, "Quantification in Biology," in Harry Woolf (ed.) Quantification: A History of the Meaning of Measurement in the Natural and Social Sciences (Indianapolis: Bobbs-Merrill, 1961), p. 210. logical stage, after the Greek "nomos" or "law." The Pythagorean Theorem, for example, defined a relationship existing between the sides of all of the right triangles, regardless of size, which were classified as such during the first, or taxonomic, stage of discipline development. In the third and final period of growth, deductive systems based on very broad postulates from which less general propositions can be logically derived are seen to develop. A substantial part of physics has entered this final, often highly mathematical, stage. Chemistry and that part of biology which has a mathematical orientation are moving gradually into it. Since the late nineteenth century, a vast number of deductive systems have come into existence. Providing great impetus to the proliferation of such systems was, of course, the realization by mathematicians of the century just past that the axioms of Euclidean geometry, particularly that which proclaimed that through a point not on a given line only one line could be drawn parallel to the given line, were not self-evident truths or given a priori to the intuition, as Kant and scholars in general had believed for some two thousand years. ${ }^{12}$ Other deductive systems in geometry, as a consequence of this discovery, seemed entirely possible and were presented as such. Even this last stage of inquiry, where systems of immense deductive fertility are seen to exist and promote fusion, has its serious limitations. The general faith of mathematical logicians in the viability of axiomatic systems was shaken in the early 1930 's by the young Viennese mathematician Kurt Geodel who demonstrated that any consistent system which is strong enough to produce natural numbers and operations

\footnotetext{
12 While Euclid's axiom still holds for everyday kinds of lines, it is not relevant for Einsteinean space where parallel lines do not exist. See Michael A. Arbib, Brains, Machines, and Mathematics (New York: McGraw-Hill, 1964), p. 120.
} 
like addition and multiplication can also contain formulae which are meaningful and true even though they cannot be proved with the system itself. Nevertheless, an academic discipline which has matured to this final stage has made a robust advance. There is a vast difference, as Northrop is wont to point out, between the immediately sensed color "blue" of the natural history stage of inquiry and the conceptual notion of "blue" in the final, or deductively formulated theory, stage of inquiry where that color is defined by its hue (or wavelength), its intensity (or the amount of energy it reflects per square centimeter per second), and its saturation, all of these characteristics deriving their meaning from the system of postulates of which they are a part. ${ }^{13}$

It would be a mistake, however, to view all activities within a particular discipline as being at the same level of development and sophistication. Indeed, in the field of biology the taxonomic activity of the botanist, or entomologist, or zoologist, and the process-oriented studies of the mathematical biologist can prove mutually reinforcing, as the morphogenetic studies of Edmund Sinnott on the relationships between form and function seem to suggest. One authority even suggests that physics, much of which is concerned with deductive systems, has its descriptive and nomological areas. And the social sciences are still, despite efforts to formulate a "social physics," by and large restricted in their activity to the descriptive and nomological levels. ${ }^{14}$ Although fission and fusion strategies are capable of coexistence (indeed must coexist in some manner), one will usually be dominant at a given point in a historical time. Gorn, it has been learned, sees either fission or fusion vis-à-vis the body of knowledge as capable of solving the

${ }^{12}$ F. S. C. Northrop, The Logic of the Sciences and the Humanities (New York: Meridian, 1959), pp. 102104.

${ }^{14}$ Caws, op. cit., pp. 280-81. See also Gerard in Woolf (ed.), op. cit., p. 210. problem of information storage and retrieval. From the vantage of one whose primary concern is with meaning and cohesiveness as the compelling reasons underlying any effort to restructure knowledge the strategy of fusion seems far more promising and imperative. ${ }^{15}$

The fused character of knowledge and its interconnectivity may be seen historically in man's employment of primitive models to explain his largely undifferentiated external reality, and later, after it was decided to organize the continuity of knowledge in fundamentally discontinuous disciplines, his adoption of more sophisticated models which, having their genesis in a particular discipline, proved their analogical suggestiveness by rapidly penetrating other fields, scholars as diverse as the educational philosopher Mare Belth and the political scientist Karl Deutsch have seen in the study of the development and pervasive diffusion of models for organizing reality a principle which might well underlie the educative process. The earliest models by which man sought to explain the universe of phenomena which impinged upon him were, of course, anthropomorphic, that is to say, an ascription of human qualities to the elements and behavior of nature. Later in the course of human history the wheel, the balance, the web of thread (with its implication of interaction), the pump and the clock (with their implication of mechanistic determinism), and the classical organism with its infused teleology or goal structure served as models. ${ }^{16}$ Models, as such, vary in character.

\footnotetext{
${ }^{15}$ Sigmund Koch suggests that recent introspection in science, education, and philosophy has reversed the emphasis on an analytico-reductive approach. See his "Psychology and Emerging Conceptions of Knowledge as Unitary," in T. W. Wann (ed.), Behaviorism and Phenomenology: Contrasting Bases for Modern Psychology (Chicago: Univ, of Chicago Pr., 1964), pp. $1-4$.

${ }^{10}$ Karl W. Deutsch, "Higher Education and the Unity of Knowledge: An Operational Approach to the History of Thought," in Lyman Bryson, Louis Finkelstein, and R. M. MacIver (eds.), Goals for American Education (Ninth Symposium of the Conference on Science, Philosophy, and Religion in Their Relation to the Democratic Way of Life [New York: Harper, 1950]), pp. 102-105.
} 
Some are mythic, that is to say, they explain unfamiliar and often frightening phenomena in terms of traditional myths such as that of Isis and Osiris in ancient Egypt, which was used, by analogy, to explain the changes of season. ${ }^{17}$ Such mythic models were most frequently inherited and learned by what Deutsch calls mimesis or unanalyzed imitation. ${ }^{18}$ A typology of models would also include the scientific, the historical, and the ideological. Scientific models, which in theory were open to empirical validation or invalidation, were used to discover, control, and predict the course of natural processes. Newton's mechanism-based model of the motion of large aggregates would be an example of a scientific model. Historical models are, to quote Belth, "concerned with the relation in thought between particular events of one time and particular events of another, and with the cumulative and directive effect that events have upon one another in the minds of men."19 Like scientific models, historical models may be mathematical (usually, at least in more recent times, probabilistic); analogical (like Marx's iron laws of history which find their analogue in both the determinism of classical physics and the psychological determinism of organismic growth in the sense of Teilhard de Chardin); or even theoretical with analogical elements (such as the cyclic methahistory of a Toynbee or a Spengler). Finally, there are ideological models which "are bound to the systematic image of an unambiguous, perfect, orderly reality, which serves as the instrument for interpreting the imperfections which are all about us as we live out our lives." ${ }^{20}$ An example of an ideological model would be that historic form of utopianism which is the scriptural communism of Marx and Lenin.

\footnotetext{
it Belth, op. cit., pp. 180-81.

18 Deutsch in Bryson et al. (eds.), op. cit., p. 79.

10 Belth, op. cit., pp. 180-84. See also Henry Margenau, Ethics and Science (Princeton, N.J.: Van Nostrand, 1964), pp. 65-66, 89-90.

${ }^{20}$ Belth, op. cit., pp. $180-84$.
}

The analogical suggestiveness of models for disciplines external to those particular disciplines in which such models have their genesis is demonstrated by the models of society currently employed in sociology, almost all of which have been imported from the biological sciences, the physical sciences, or mathematics. These include such models as the evolutionary, the organismic, the equilibrium, the classical physical science, and the statistical-mathematical. ${ }^{21}$ The cascading quality of analogical suggestiveness may be seen in the transposition of the notion of entropy from its original locus in thermodynamics to a central position in information theory and, via information theory, into numerous other disciplines. Using Claude Shannon's articles on information theory in the July and October 1948 issues of the Bell System Technical Journal as a conceptual unit capable of diffusion, Randall Dahling traced, through the examination of publications, the way in which this conceptual innovation penetrated the various disciplines. In addition to its evocative qualities, Dahling determined that the notion of information theory spread because: (1) communication is a common ground for many disciplines; and (2) because its mathematical formulation and methodology was appealing to natural scientists and the increasingly sizeable group of social scientists which is oriented to quantification. ${ }^{22}$ In the final analysis the adoption of a conceptual innovation by scholars in disciplines

${ }^{21}$ See Alex Inkeles, What Is Sociology? An Introduction to the Discipline and Profession (Englewood Cliffs, N.J.: Prentice-Hall, 1964), pp. 28-46.

${ }^{22}$ Randall L. Dahling, "Shannon's Information Theory: The Spread of an Idea," in Studies of Innovation and of Communication to the Public (Studies in the Utilization of Behavioral Science, XI [Stanford: Institute for Communication Research, Stanford Univ., 1962]), pp. 119, 136. Chronologically, the diffusion of the information theory concept followed this order: communications engineering, psychology, physiology, physics, linguistics, biology, sociology, optics, statistics, and journalism. It is to be anticipated that more can be learned about the spread of ideas from the citation network studies of Derek Price at Yale, Eugene Garfield at the Institute for Scientific Information, Ben-Ami Lipetz in Carlisle, Mass., and Norman Kaplan at George Washington University. 
external to its source seems to rest with some notion of congruence or "fit" between the "culture" (or set of intellectual commitments) of a potentially receptive discipline at a given point in time, and the nature of the new idea itself. Incongruence between a potentially pervasive concept and the existing Weltanschauung shared by the set of potentially receptive scholars in an external discipline can result in a lag in the adoption of the concept whose implications, for a variety of possible reasons, cannot be immediately sensed. ${ }^{23}$ It is entirely possible, moreover, that the cross-disciplinary utility of concepts increases as such concepts undergo an evolutionary process of refinement and reinterpretation in their disciplines of origin. Etymologically, for example, the concept of force had a strongly animistic cast. Its progressive refinement at the hands of Aristotle, Galileo, Kepler, Newton, Kant, Mach, and Hertz has resulted in the present period in a concept of force which is almost purely mathematical in meaning, that is to say, without immediate physical referents. ${ }^{24}$

The capacity to be able to predict the diffusion of an idea into adjacent domains, even on a probabilistic basis, could have important implications for the ongoing organization of information in libraries, and for the restructuring of the bibliographic devices which provide access to that information. Even without such predictions, as Don Swanson has suggested, adequate circulation information and the careful observation of inlibrary user behavior would permit the association of users with those portions of the graphic record which they use,

${ }^{23}$ See Elihu Katz, Margin L. Levin, and Herbert Hamilton, "Traditions of Research in the Diffusion of Innovation," American Sociological Review, XXVIII (April 1963), 240, 249-50.

$\approx$ The evolution of the concepts of space, force, and mass have been considered in several books by Max Jammer. See William R. Catton, Jr., "The Development of Sociological Thought," in Robert E. L. Faris (ed.), Handbook of Modern Sociology (Chicago: Rand McNally, 1964), p. 935. in such a way that the development of new fields like bionics (or artificial intelligence) might be anticipated on the basis of the significantly large common group of library users which is making intensive use of the literature of neurology and information theory. ${ }^{25}$ To be sure, citation analysis might well provide information on patterns of concept diffusion, however, the time differential between the actual acceptance of an externally generated concept by a receptor field and the first publication in that field employing the concept is substantial enough to render such an approach overly a posteriori to be of real utility in the restructuring of bibliographic arrangements.

Another way of conceptualizing the growth of knowledge is within a framework of progressive subordination, via hierarchical ordering, of old concepts, theories, and hypotheses to new ones. Such subordination imparts to the structure of knowledge a "nesting" effect in which newer, more abstract concepts serve as receptacles for the older, less abstract concepts which are their special cases. Another image would be that of intersecting continua. If a vertical continuum ranging from "less abstract" to "more abstract" is developed to intersect with a horizontal continuum moving from "less analogically suggestive" to "more analogically suggestive," the relationship defined by the line $x y$ in the following diagram could be expected to develop.

The line $x y$, it can be seen, expresses the direct relationship between abstractness and analogical suggestiveness. Lest the foregoing seem overly tautological, it can be speculated that the abstract concepts of "uncertainty" and "complementarity" (or the duality of wave and particle motion) in quantum physics,

${ }^{25}$ Don R. Swanson, "Dialogues with a Library Machine" (Chicago: Graduate Library School, Univ. of Chicago, n.d. [Mimeographed]), p. 9. 


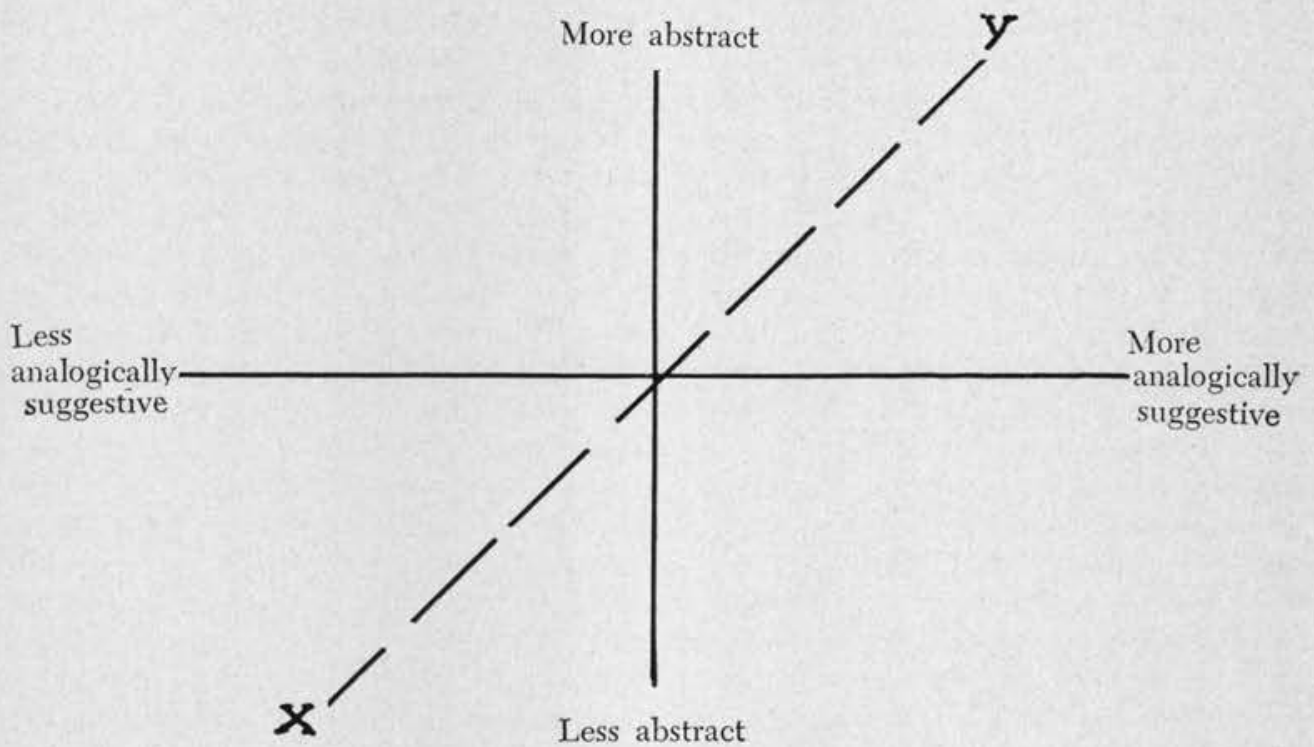

not to mention the emerging principles linking matter and anti-matter, will suggest more about the nature of social phenomena and, by extension, about the limits of explanation in the social sciences than any of the concepts heretofore imported into this broad area of inquiry. Moreover, any general theory which claims to explain behavior in a plurality of phenomenal systems must be sufficiently abstract and deductively fecund to account not only for already observed ismorphism in a diversity of behavioral realms but also for behavior in systems which have not yet been empirically identified. Returning to the hierarchical ordering of concepts according to comprehensiveness, Boulding has observed that-

The old is almost invariably seen as a special case of the new. Algebra generalizes the operations of arithmetic. The calculus generalizes some operations of algebra. The theory of games is a generalization of the theory of simple maximization. In physics, Newtonian mechanics is seen as a special case of the mechanics of relativity. In economics, the Keynsian system is easily seen as the generalization of the classical system. ${ }^{26}$

The excellent studies of Thomas Kuhn on the revolutionary character on paradigm change in science ${ }^{27}$ notwithstanding, it would seem that there is a continuity in the development of knowledge which is remarkably antithetical to revolution. Michael Polanyi suggested this continuity when he characterized the Copernican system as no less anthropocentric than the system of Ptolemy in that the former satisfied man's need to abstract as well as the latter exploited the enjoyment men find in the use of their senses. ${ }^{28}$ Indeed, Leonard Nash

${ }^{20}$ Boulding, op. cit., pp. 77-78. See also Leonard Nash's distinction between "falsification" and "subordination" (or incorporation) in The Nature of the Natural Sciences (Boston: Little, Brown, 1963), pp. 286-96.

${ }^{27}$ See Thomas Kuhn, The Structure of Scientific Revolutions (Chicago: Univ. of Chicago Pr., 1962).

${ }^{28}$ Michael Polanyi, Personal Knowledge: Toward a Post-Critical Philosophy (London: Routledge and Kegan Paul, 1958), pp. 3-4. It might not be unthinkable to suggest that the Ptolemaic system was a rape of precisely those capacities which distinguish man from lower orders of living systems, namely, his ability to abstract and theorize. Nash has observed that despite the overthrow of the Ptolemaic system by the Copernican, astronomers continued to speak of the regularity of motion, orbits, and objects in the sky. See Nash, op. cit., pp. 284-92. 
has used the term evolution to describe the growth of science. Invoking the analogy of organisms evolving toward higher levels of organized complexity, he supports the image, originally proposed by Samuel Sambursky, of science as advancing by "concentric approximations," that is to say, through viewing new, more abstract theory as possessing many of the components of the theory or theories that it has subordinated..$^{29}$ It may not even be stretching the point to suggest that the development of new paradigms in science approximate the emergence of new species in biology. The principle of ontogeny recapitulating phylogeny suggests that the life history of an individual organism from conception on takes it through roughly the same stages that evolution took that species of organism up to the time the individual organism came into existence. In much the same way, a new, comprehensive theory in science typically incorporates the lower order theoretical structure which had developed in science up to that time, but represents an improvement on the latter in its organizational and correlative powers. ${ }^{30}$

There are other ways in which the fundamental continuity of knowledge may be observed, in the humanities as well as the natural and social sciences. A familiar form of identifying continuities in literature and other humanistic disciplines is through the analytical isolation of those formative structures that Jung called archetypes, or primordial ideas which are rooted in the collective unconscious of the human race. ${ }^{31}$ Jung

\footnotetext{
29 Nash, op. cit., pp. 286-88.

${ }^{30}$ In a somewhat different but analogous context, Talcott Parsons has defined an "evolutionary universal" as "a complex of structures and associated processes the development of which so increases the long run adaptive capacity of living systems in a given class that only systems that develop the complex can attain certain higher levels of general adaptive capacity." See his "Evolutionary Universals in Society," American Sociological Review, XXIX (June 1964), 340-41.

${ }^{21}$ These archetypes may be distinguished from Plato's ideas or the categories of Kant in that they are not completely a priori, having had their genesis in man's
}

conceived archetypes less in terms of inherited ideas about love or religion or, more negatively, about the perversion of love in lust or hatred, but rather as the inherited potential for such ideas, a potential which began to cumulate at that point in historical time when man became conscious of himself as somehow different or set apart from the rest of nature ${ }^{32}$ Briefly defined, archetypes are symbols which "carry the same or very similar meanings for a large portion, if not all, of mankind." ${ }^{33}$ In the archetypal mode of literary evaluation, the focus is on the genesis and persistence in literature of symbolism such as day and night, spring and autumn, birth and death, innocence and experience, and on such provocative figures as Faust, Odysseus, Satan, and Prometheus. There are dangers, of course, in the inappropriate use of archetypes in the explanation of literature. One is reminded of Douglas Bush's witty comment on archetypes: "Some ideas, such as frustration, became master keys for opening all doors. A crowd of authors and characters were seen trudging along the road back to the womb. Along a parallel road stumbled another crowd driven by the death wish." 34

Some archetypes, it may be supposed, can be explained by certain constraints of the natural order. Physically, all men are subject, at least in their natural state, to the laws of gravitation. As a consequence, the obstacles to vertical move-

own primordial experiences. See Carl Gustav Jung, Collected Works (Vol. IX, The Archetypes and the Collective Unconscious [New York: Pantheon, 1959]), pp. $3-4,16,23$. Jung has referred to archetypes as the "residua of racial experience." See Maud Bodkin, Studies of Type-Images in Poetry, Religion, and Philosophy (London: Oxford University Press, 1951), p. 9. See also Jolande Jacobi (ed.), Psychological Reflections: An Anthology of the Writings of C. G. Jung (New York: Harper, 1953), pp. 38-39.

See Jacobi (ed.), op. cit., p. 36. Jung likens archetypes to receptacles which are filled in by the cultural experience of a lifetime.

${ }^{3}$ Philip E. Wheelwright, Metaphor and Reality (Bloomington: Indiana Univ. Pr., 1962), pp. 111-12.

" As quoted in William C. DeVane, Higher Education in the Twentieth Century (Cambridge, Mass.: Harvard Univ. Pr., 1965), p. 111. 
ment of an upward sort are more formidable than those confronting one who seeks to go down. Therefore, the basic notions of dominance, achievement, loftiness, and excellence, all of which represent states one must struggle for, are associated with upward movement rather than with the ease of downward motion..$^{35}$ Most archetypes, however, are elusive and their essence can be only indirectly explained through the use of imperfect metaphors. Nor does continuity in archetypal meaning always prevail, everywhere and in every period. Symbolically, the wheel as archetype, may have either positive or negative significance. In the East it has the positive connotation of the persistent cycle of birth, death, and rebirth. In the West, it has a more ominous symbolic meaning related to the role of fortune (for example, the wheel in the game of roulette) in determining one's success or failure. $^{36}$ Fustel de Coulanges devoted most of his life to studying the elements, particularly religious beliefs informed by archetypes, influencing the growth of Greek and Roman institutions, particularly the life of the city. ${ }^{37}$ Mircea Eliade has sought to identify the formative concepts at work in a number of archaic societies, and found in the course of his investigations that time and the flow of history in such societies is regulated mainly by the operation of archetypes. These archetypes expressed the ontology of primitive societies like those of ancient Mesopotamia or aboriginal Australiasocieties which largely lacked the philosophical language to express their notions of being and reality. The ontology of such societies had to be inferred from their rites, symbols, and myths. ${ }^{38}$ It was

\footnotetext{
as Wheelwright, op. cit., pp. 111-12.

so Ibid., p. 126.

эr See Numa Denis Fustel de Coulanges, The Ancient City: A Study on the Religion, Laws, and Institutions of Greece and Rome (Garden City, N.Y.: Doubleday, 1956), pp. 11-14, 142-73.

ss Mircea Eliade, The Myth of the Eternal Return (New York: Pantheon, 1954), p. 3.
}

observed that the life of primitive man was fulfilled only to the extent that he performed certain paradigmatic gestures or spoke symbolically powerful words which originated with the celestial gods. The mountains that he climbed, the land that he cultivated, the rivers that he navigated, all of the acts of primitive man, found their meaning in the archetypal actions primordially performed by transcendent gods. The temples and cities of ancient men were also patterned after such extraterrestial prototypes. Babylon, for example, was surrounded by a vast circular territory bounded by a river (the Euphrates) in precise imitation of the Babylonian vision of a celestial heaven. ${ }^{39}$ In the sense that these godly actions took place at the beginning of time, the ancient man participated in the beginning of things through their re-enactment.

Two of the most fundamental archetypes which recur in philosophy and religion as well as literature are those of saving wisdom and spiritual rebirth. ${ }^{40}$ Northrop Frye has proposed that these and other very powerful archetypes are embodied in the Greek classics, especially Homer, and in the Bible and have reverberated through literature to the present period. He sees the myths of creation and fall in Genesis and of the pastoral life as the strongest formative principles in religion and social, political, and philosophical thought. ${ }^{41}$ Put another way, literature from the end of the first century A.D. to the present is mainly derived and mimetic, deriving its thematic content from the past and its substantive content from its own historical period in much the same way that a Jungian archetype maintains its form while wear-

\footnotetext{
see ibid., pp. 9-10.

${ }^{40}$ Bodkin, op. cit., pp. $35,175$.

${ }^{4}$ See Northrop Frye, "The Developing Imagination," in Learning in Language and Literature (Cambridge, Mass.: Graduate School of Education, Harvard Univ., 1963), pp. 31-60. Also his "Introduction" in Northrop Frye (ed.), Design for Learning (Toronto: Univ. of Toronto Pr., 1962), pp. 3-17.
} 
ing the experiential clothing of different eras. In this perspective, literature is the embellishment and elaboration of timeless themes. The literateur, in the final analysis, has no really new stories to tell. This thematic continuity is described by Frye in the following way: "At a point in the narrative, recognition point, or as Aristotle calls it anagnorisis, the reader knows what is going to happen, but he wishes to continue participating in the completion of the design." 42

As units of discourse in literary criticism, archetypes are conceptually important since they impart to literature its characteristic forms. ${ }^{43}$ Even in music, one can sense that "inner unity of symbolic forms" that Ernst Cassirer saw as providing a basic homogeneity to human culture. ${ }^{44}$ Leonard Meyer, bridging between music and psychology, has hypothesized that meaning in music may be interpreted in terms of the amount of congruence which prevails between one's generalized expectations about what will come next in a score and what actually does. Skill in composition then rests with the composer's ability to manipulate this tension of expectation which is general for most of mankind. Music which satisfies man's every expectation is, in this theory, highly redundant and boring to the musical gourmet. It is from the uncertainty of music and its probabilistic character that man draws his pleasure. ${ }^{45}$ Great composers, like Beethoven and Mozart, achieve simultaneously a maximum of uncertainty or surprise and a maximum of

42 Frye makes many incisive comments on this problem in his "The Road to Excess" in Myth and Symbol: Critical Approaches and Applications (Lincoln: Univ. of Nebraska Pr., 1963), pp. 3-38.

Northrop Frye, Anatomy of Criticism: Four Essays (Princeton, N.J.: Princeton Univ. Pr., 1957), pp. 34142.

" See Cassirer, An Essay on Man: An Introduction to a Philosophy of Human Culture (New Haven, Conn.: Yale Univ. Pr., 1944), pp. 67-68, 70-71, 222.

45 There are some parallels here with the measures of information transmission in information theory. fulfilled expectations. ${ }^{46}$ To the continuities and discontinuities of the music, man brings his generalized aesthetic tension. From the foregoing it can be seen that both literature and music, though by and large in the stage of taxonomy or naive induction, are capable of sustaining conceptual frameworks which articulate the parts of the whole. Within this perspective, chronological classification or grouping by form seem primitive indeed as organizing principles in literature and music. Frye has contended, as a matter of fact, that ultimately literature, like mathematics, has a self-contained form and a system of postulates which require no empirical referents. $\mathrm{He}$ has even wondered, though partially discarding the notion, whether the same formative structures which recur in the history of literature are operative in other fields which are dependent on verbal structures, like metaphysics, theology, history, and law. ${ }^{47}$ At all events, in literature and music, indeed in the humanities generally, there are scholars devoted to Matthew Arnold's precept of "letting the mind play freely around a subject in which there has been much endeavor and little attempt at perspective." 48 From the point of view of the writer, the foregoing demonstrates that there are elements of structural continuity in several fields of the humanities and that where structure persists over time, even in the midst of seeming uniqueness, the prospect for systemic outlook is radically improved.

Corresponding to the archetypal patterns which structure the products of artistic activity are what Gerald Holton has called the "themata" of science. It is increasingly sensed in scientific quarters that there are elements at work in

\footnotetext{
4e Leonard B. Meyer, Emotion and Meaning in Music (Chicago: Univ. of Chicago Pr., 1956), pp. 1-42.

4T Frye, Anatomy of Criticism, pp. 350-54.

4s Quoted in ibid., p. 3.
} 
the process of theory construction, as well as discovery and justification, which are not verbalized or made explicit but which, nevertheless, seem to possess an historic continuity. ${ }^{49}$ At least one prominent scientist sees the primordial formulations of science, which persist even to the present day, as deriving mainly from the unanalyzed depths of human consciousness and as receiving their initial embodiment in religion and philosophy. ${ }^{50}$ As a result, so the argument goes, a large part of the history of science can be interpreted as a continuing dialectic between those who would emphasize stability and being (as atomism) and those who would emphasize becoming (reality as a continuum), positions which had already received reasonably refined formulation in Greek philosophy. ${ }^{51}$ René Dubos has noted that

. . the theory of dynamic equilibrium, which was the last word in biochemical sophistication when first enunciated three decades ago, is now being questioned again by a new generation of biochemists. In a very recent series of lectures an eminent biochemist suggested that life might reside in the stability and continuity of nonliving macromolecules within the cells, rather than in the transformation of components which undergo rapid turnover. According to this biochemist, in other words, the course of life might be found in the Cartesian concept of "being" rather than in the concept of "becoming" which had its origin in Heraclitus of Ephesus. . . . ${ }^{52}$

40 Koch in Wann (ed.), op. cit., pp. 21-22. See also Polanyi, op. cit., pp. 15-17.

${ }^{50}$ René Dubos, The Dreams of Reason: Science and Utopias (New York: Columbia Univ. Pr., 1961), p. 123.

${ }^{51}$ In his The Edge of Objectivity (Princeton, N.J.: Princeton Univ. Pr., 1960), Charles Gillespie contends that atomism (or atomicism) has been the most productive organizing structure in the history of science. See Dubos, op. cit., pp. 120, 126, 128.

${ }^{52}$ Dubos, op. cit., p. 124. Harvey Brooks has observed that the stability of dynamic equilibrium, seen macroscopically, may turn out, microscopically, to be a flux of opposing motions which simply cancel each other out. See his "Scientific Concepts and Cultural Change," Daedalus, XCIV (Winter 1965), 73.
Less Jungian in tone and in general less speculative with regard to the possible sources of persisting images in science is Holton's discussion of themata. ${ }^{53}$ He begins by citing the recent discovery by Alexandre Koyre that Newton suppressed and failed to publish in Book III of his Principia, a fifth rule of reasoning in philosophy which read, in part, as follows: "Whatever is not derived from things themselves, whether by the external senses or by internal cogitation, is to be taken for hypotheses. ... And what neither can be demonstrated from the phenomena nor follows from them by argument based on induction, I hold as hypotheses." ${ }^{4} 4$ As operative in science, themata are propositions which are "entirely unverifiable and unfalsifiable, yet not quite arbitrary. ..." What may be called the contingent plane of science-that is to say: (1) statements which are empirically based; and (2) statements deriving from logical or mathematical processesis thus seen as overly limiting. ${ }^{55}$ Holton believes that any complete understanding of theory construction in science must take into account a thematic dimension as supplement to the two-dimensional contingent plane. $\mathrm{He}$ suggests, for example, that the thematic component of the concept of force is the masculine principle of potency. This principle of potency has been differently incarnated at various points in human history by scholars as diverse as Aris-

${ }^{53}$ Holton would not go so far, for example, as Kant who saw the "categories" as prior to human experience and functioning as stereotyped intellectual equipment common to all men. See Deutsch in Bryson et al. (eds.) op. cit., p. 58.

s4 Gerald Holton, "Presuppositions in the Construction of Theories," in Harry Woolf (ed.), Science as a Cultural Force (Baltimore: Johns Hopkins Pr., 1964), p. 83.

S5 Force, for example, can be "observed" empirically in the deflection of solid bodies as detected by a measuring instrument. The logical or mathematical dimensions of force as it operates in the contingent plane of science are to be found in the mathematical laws of vector calculus. 
totle, Galileo, and Newton, among others. The persistence of the potency themata can be seen in the early failure of seventeenth-century natural philosophers to distinguish between the Aristotelean notion of force as that which produces motion or velocity and the Galilean concept of force as that which produces a change in velocity or acceleration, that is to say, a ball to which one imparts motion will continue to roll along a reasonably friction-free horizontal plane even after one has ceased to impart motion to it. ${ }^{56}$ Other themata are those of (1) conservation of energy; (2) atomism; (3) the probabilistic character of behavior; and (4) the behavior of things as a consequence of their shape (for example, the earth rotates because of its near sphericity). A striking example of themata in action is provided by the contemporary controversy between the evolutionary and steady state theories of cosmology and the more ancient Milesian and Parmenidesian cosmologies. The fission of primeval matter and its later fusion in Milesian cosmology has its echo in the expansion-contraction cycles of the more modern pulsating universe of the evolutionary theory. And the steady state hypothesis may, of course, be equated with the ideas of Parmenides. In general, themata are ascendant or obscure in various intellectual epochs because of the seeming relevance of their power to structure reality. With the rise and fall of scientific fashions, they are utilized or put into storage but are never really disposed of or discarded with finality. ${ }^{57}$

It may perhaps be argued that the foregoing extended discussion of structural continua in the history of the sciences and the humanities is overly superficial and that any investigator seeking to identify historical discontinuities would be, at least, equally rewarded. That may be so, and yet one cannot fail

se See Northrop, op. cit., pp. 22-34.

st Holton in Woolf (ed.), Science as a Cultural Force, p. 101. to be somewhat impressed by certain functional parallelisms between themata and archetypes. Indeed, a reasonable extension of general systems theory, however quasi-scientific, might be to seek ismorphism between archetypes and themata as they are employed respectively, to organize the reality of the humanist and the scientist. At all events, the continuities represented by such formative elements might well provide a useful historical adjunct to the emerging recognition of general theories of systems. At this point in the course of the paper, it may be appropriate to consider the attempts which have been made to view knowledge as a structural unity, particularly as such integrative structures have been supportive of general education in colleges and universities.

Historically, efforts to view knowledge holistically begin with the philosophers of classical Greece and run all the way to the general systems theorists of the twentieth century. In the Sophist, Plato directly concerned himself with knowledge in its unity and diversity. And the seventeenth and eighteenth centuries were especially characterized by efforts to see knowledge whole. Descartes' paradigm for the unification of knowledge, as explained in his Discourse on Method, was a primitive reduction of all knowledge to the relationships at that time, seen as inherent in geometry. Francis Bacon, in his Novum Organum, sought to unify knowledge through limiting it to the output of those areas of inquiry which were amenable to the application of natural philosophy. Leibnitz and the French Encyclopedists deplored as artificial the arbitrary division of knowledge into subject matters, but differed in their plans for the encyclopedic organization of knowledge. The former, in his projected encyclopedia, would have made the logical (or synthetic-theoretic) ordering of knowledge primary and would have employed an index to provide classification by subject. Diderot 
and d'Alembert, the French Encyclopedists, made classification by subject primary and utilized a cross-reference arrangement to demonstrate horizontal connections. Kant, in radical disagreement with his predecessors, saw each subject matter as a self-contained logical system whose place in the total scheme of things was defined a priori by knowledge as an organic whole. For Descartes and Leibnitz, knowledge was simply the sum of its constituents. For Kant, all knowledge was a system and the discrete subject matters were logically selfcontained subsystems whose articulation within the organic whole was defined by the system itself. ${ }^{58}$ In Kant's judgment, therefore, the division of knowledge was anything but arbitrary. Throughout the course of history the unification of knowledge has been seen as a desirable goal, at times simply for its own sake, at other times for the sake of its redeeming social importance-that is to say, the periodic demand for knowledge codification as essential to the coordination of human and physical phenomena in the practical sphere. The efforts to unify knowledge have been formally embodied in the formation of special groups (like the Society for General Systems Research, and the Foundation for Integrative Education); in the construction of encyclopedias (like the International Encyclopedia of Unified Science); and in the educational efforts of Comenius and the Pansophists or the formulators of the encyclopedic curricula in the eighteenth century universities of what is now Germany. ${ }^{59}$

\footnotetext{
ss Caws has suggested that, vis-à-vis the discrete sciences, there is a methodological unity based on the sharing of a single logic. See op. cit., p. 336 .

${ }^{3}$ See Robert McRae's excellent discussion of efforts to unify science during the seventeenth and eighteenth centuries in his The Problem of the Unity of the Sciences: Bacon to Kant (Toronto: Univ. of Toronto Pr., 1961), especially $v-x, 3-23$. See also William O'Meara, "Observation, Interpretation, and Integration," in F. Champion Ward (ed.), The Idea and Practice of General Education (Chicago: Univ. of Chicago Pr., 1950), pp. 235-37, where the strategies employed in attempts to integrate knowledge are classified as encyclopedic, theoretical, and practical.
}

During the two decades preceding 1950 , physics (or better, physical statements which had been purged of all metaphysical content) was seen as the prime discipline to which all other scientific disciplines could be reduced. ${ }^{60}$ The same kind of disciplinary ethnocentrism which had earlier made theology and geometry the measure of all knowledge now made physics the keystone of the twentieth-century edifice of knowledge. ${ }^{61}$ Of late, however, the notion of emergence, which is the inverse of reduction, has been popular. Like reduction, emergence implies the idea of hierarchical order, but the focus is on the ascendant rather than the descendant nature of vertical order. Caws has provided this description of the process of emergence:

We say that one science is emergent with respect to another if there is some event described and explained by the former, whose parts are described and explained by the latter, such that no combination of the explanations of the parts as described by the latter can be made to yield an acceptable explanation of the whole as described by the former. Psychology would, according to this criterion, be emergent with respect to physiology if no set of explanations of brain structures could be made to yield an acceptable explanation of, for example,

\footnotetext{
${ }^{60}$ Described by Rudolf Carnap as quantitative description of space-time-place. See Joergen Joergensen, The Development of Logical Empiricism (International Encyclopedia of Unified Science, Vol. II, No. 9 [Chicago: University of Chicago Press, 1951]), pp. 81-82. The logical empiricists, in general, tried to avoid the ambiguity and metaphysical pregnance of natural observational language. P. W. Bridgman, for example, developed the notion of operations in which he did not deny the possible existence of that which could not be subjected to the operations of measurement, but did deny the scientific validity of concepts which did not possess a corresponding set of operations-operations which, contrary to widespread understanding, could be either physical or mental. An example of the latter would be mathematics in which one desires to determine whether a series of magnitudes is continuous. See Caws, op. cit., pp. 319, 321-22 and Joergenson op. cit., p. 56 .

e1 Such reduction can be viewed in the image of a chain-from sociology to psychology to biology to chemistry to physics. See O'Meara in Ward (ed.), op. cit., p. 233. Caws has suggested that the sciences which formed the links in this chain of reduction had, at least in part, to have reached the nomological (or generalized empirical theory) stage of inquiry. See Caws, op. cit., p. 283.
} 
some exhibition of problem solving behavior ... . the defender of emergence would claim that there is something about the whole event as described in the emergent science to which the concepts of the science from which it is emergent are not even relevant. The whole, he would say, is greater than the sum of its parts. . . ${ }^{62}$

The historic search for integrating principles in American higher education is interesting to review, especially in light of the efforts at knowledge unification just discussed. During a substantial part of the nineteenth century, and even before that in what William Cowley calls the classical American literary college, a course in moral philosophy, typically taught to seniors by the president of the college, was regarded as the integrative capstone of the curriculum. Such courses were ordinarily a curious melange of religious orthodoxy and personal opinion. At Williams College, for example, President Mark Hopkins, who could without exaggeration be called the worst sort of dilettante, described his course in moral philosophy as covering "man in his unity and God in his sovereignty." 63 In Catholic institutions of higher learning, theology, by virtue of the nobility of its object (God) and the reliability of its sources (Divine Revelation as interpreted within the teaching authority of the Church), was viewed as the queenly discipline to which all others were ultimately linked. ${ }^{64}$ In the 1930 's and 1940's Robert Maynard Hutchins championed the primacy of metaphysics, not simply as the study of first principles, but of

\footnotetext{
eaws, op. cit., pp. 308 and 309.

as Quoted in Rudolph, op. cit., pp. 140-41. There is considerable evidence that Hopkins, though apparently popular with students and alumni, was an anti-intellectual who eschewed Kant and had not even read Darwin or Huxley. He was not, in a phrase, the kind of professor that a really able student would like to have seated opposite him on a log. See Bruce Dearing, "The Myths about the College Teacher," Saturday Review, XIVII (January 1964), 65.

'See Vincent E. Smith, The School Examined: An Essay on the Curriculum (Milwaukee: Bruce, 1960), pp. 70-94. Christoper Dawson, the noted historian, has more recently suggested the study of Christian civilization as an integrating principle in higher education.
}

all that such principles imply for behavior in human and nonhuman reality. ${ }^{65}$ Yet in the late 1940's and early 1950's, the innovating college at the University of Chicago was by no means oriented to the Great Books or even the metaphysics of classical antiquity. To be sure, philosophy and history did serve as the disciplines of integration in the curriculum, but the selections from original works, syllabi of "Great Snippets" as they were called, the content of which was ordered by philosophical and historical principles, were quite modern in origin and the medieval period was, on the whole, rather underrepresented. The objective of this curriculum was to develop in students the capacity to think critically and judge wisely. ${ }^{66}$ There are many indeed who view the "Old College" at Chicago, with its symbol of erudition and intellectual high play-Aristotle Schwartz -as a remarkably successful experiment in higher education. Those who implemented the college curriculum were concerned that the students grasped ideas and methods and that they learned a little bit about the different ways in which knowledge might be structured. They were not interested in stuffing students with subject matter and low-order empirical content. ${ }^{67}$ It is curious that in the latest reorganization of the college, adopted within the last few months, there is the suggestion that the older emphasis on acquainting students with the structure of knowledge, despite the intervening increase in low-order empirical knowledge, is no longer viable.

6s Robert Maynard Hutchins, The Higher Learning in America (New Haven, Conn.: Yale Univ. Pr., 1936), pp. 107-108.

F. Champion Ward, "Principles and Particulars in Liberal Education," in Cohen (ed.), op. cit., pp. 122-23, 127-28.

67 Richard McKeon has given an account of the shift away from an emphasis on discipline and method, which prevailed in the medieval period, to a concern, in the Renaissance, with the facts and data of individual subject matters. One of the fundamental objectives of the pre-1953 college curriculum at the University of Chicago was to sensitize the student to how bits and pieces of knowledge might be articulated in knowledge viewed as a seamless, but complex, whole. See McKeon in Cohen (ed.), op. cit., p. 168. 
Apparently the older ideal will survive only in the so-called "collegiate division" (or Division of Integrated Studies), one of the five divisions in which a student may now concentrate. ${ }^{68}$

Prior to 1942 , the integration course in the college of Chicago was called "Methods, Values, and Concepts." After that year, it was known as Observation, Interpretation, and Integration and aimed at giving the student an "opportunity to acquire the knowledge and capacity necessary to work out for himself an intelligent theory on the interrelationships of the fields of knowledge."69 A similar course, called "Organization, Methods, and Principles of Knowledge," still exists at Shimer College, a small experimental institution located at Mount Carroll, Illinois, which adopted the Chicago College Plan of general education in the early 1950's and has promoted its evolution. ${ }^{70}$ In the main, however, the various concepts of general education which were formulated earlier in the century are encountering rough sledding. Substantive innovations like the sequence of courses in contemporary civilization adopted by Columbia College in 1919, the broad humanities courses developed at Reed College in 1921, and the earlier attempt at Chicago to formulate a course on the Nature of the World and Man $(1924)^{71}$ have, it appears, few imaginative parallels in the present period. It is true, of course, that in portions of the country-for example, New England with its Goddard and Marlborothere are colleges which continue to em-

\footnotetext{
68 The others are Physical Science, Biological Science, Social Science, and the Humanities. See Wayne C. Booth, "The New College," The University of Chicago Magazine, LVIII (November 1965), 8-10. It is freely admitted that a major rationale of the reorganization was to link the college more closely to the interests and commitments of the graduate divisions and to check the flow of faculty away from a commitment to undergraduate teaching and towards an interest in the discipline-oriented research and graduate teaching of the subject departments.

O'Meara in Ward (ed.), op. cit., p. 234.

${ }^{70}$ See the Shimer College Catalogue, $1964-1965$ (Mount Carroll, Illinois: Shimer College, December 1963), pp. 3,39 .

${ }^{71}$ See Rudolph, op. cit., pp. $69,76$.
}

phasize those principles upon which institutions like Bennington and Sarah Lawrence were founded earlier in the century, namely, Freudian psychology and the educational philosophy of Dewey. It is also true that there are new colleges being based on technological innovations, or on what this writer would call secondary innovations when contrasted with a primary innovation like the restructuring of knowledgeeven though, for example, the construction of programed educational materials does result in the rethinking of how subject material can be most adequately presented. There is also the call for colleges with a concern for their impact on the values of students and with the posing of relevant sets of value alternatives for student choice. ${ }^{72}$ There are even colleges, like Shimer and Monteith College of Wayne State University, which are devoted to constant review of the way in which knowledge is organized for transmission to students. By and large, however, there is relatively little effort in the universe of higher education at organizing knowledge within frameworks which are fundamentally new, and it almost seems as if those engaged in higher learning are waiting for a final theory of learning based on neurophysiology or an epistemologically perfect conceptualization of "reality." Perhaps this assessment of things as they now stand is overdrawn and unfair, however, since there are many factors constraining the development and implementation of schemes of general education. ${ }^{73}$

\footnotetext{
72 Such a concern has been reflected recently in the presidential remarks of both Nathan Pusey of Harvard and John Sloan Dickey of Dartmouth.

73 Chicago of course has substantially modified its pre-1953 program of prescribed studies in general education and now permits students to elect major concentrations. Columbia College has also, in recent years, cut back on its two-year sequence of integrated social science studies called "Contemporary Civilization." Both actions, while obviously motivated by a multiplicity of factors, suggest that the prescription of general content for all may be less viable as a strategy than to modify the presentation of general content so as to fit the cognitive structure of the individual learner.
} 
Not the least of the constraints effecting general education at any level of higher education are the subject organization and narrow emphases of graduate study. Scholars who develop a general orientation do so, one suspects, almost in spite of what they have been exposed to, with minor exceptions, during their upper division undergraduate and graduate preparation. In addition, there is the widespread assumption that general education is being squeezed out by the percolation of specialized interests from the graduate schools standing above and the appropriation of its very content by the high schools positioned below. As the recent dialogue between David Truman and Jacques Barzun revealed, however, there is by no means general agreement on the nature of this squeeze-indeed, on whether or not any squeeze actually exists. ${ }^{74}$ If Freud, Dostoevsky, and Marx were traditionally read in the good colleges during a student's lower division years, it is not now precisely clear what having "had" these authors in high school really means. It may, of course, mean that the high school student has genuinely grappled with the ideas contained in those words. It may also mean, on the contrary, that the acquaintance which he developed with these authors was superficial and that he has no sense of the importance of their writings in the larger context of knowledge. With respect to the articulated structure of education and the ways in which higher

\footnotetext{
${ }^{74}$ David Riesman, reviewing a report on Princeton men made by Roy Heath in the mid-1950's, noted that those students who prepared senior honors theses severely limited the scope of their topics "in that mysterious way in which a college senior will say of himself, T'm a biophysicist with an interest in the morphology of the cell,' or 'Tm in eighteenth-century literature.'" See Roy Heath, The Reasonable Adventurer: A Study of the Development of Thirty-six Undergraduates at Princeton (Pittsburgh: Univ. of Pittsburgh Pr., 1964), xiii. Robert Wolff has even more recently observed that upper division undergraduates are, in many of the strong autonomous and universitybased liberal arts colleges, taking courses which are in reality baby graduate courses and writing senior honors theses which are in effect baby dissertations. See his "The Race to College," Atlantic, CCXVI (November 1965), 147.
}

levels influence lower levels, Robert Wolff comments:

Once more, the education of the present, for which the student gave up so much in high school, is sacrificed to the demands of the future. ... Each present was sacrificed to the future, until the presents were all pasts, and the future an empty present. It is a familiar enough story in our society. We call it prudence, or deferral of gratification, depending on our tastes in moral discourse. ${ }^{75}$

Commitment to general education, or the view that knowledge should be looked at as a coherent and integrated whole, appears to provide limited payoffs-at least on the surface-for faculty members as well as students. After all, most institutions of higher education are discipline oriented, and rewards accrue to both students and faculty on the basis of their intradisciplinary performance. The marginality of general education, particularly with respect to the ongoing educational activities of the large universities, lies in its very definition as an approach which is nonspecialized, indeed those who espouse it often have a genuine aversion to academic specialization and its ultimate usefulness. ${ }^{76}$ It cannot be denied, of course, that general education attracts the best and worst kinds of men, those who are capable of transcending specialization and those who, failing to make the grade in a particular discipline, try it as an alternative. ${ }^{77} \mathrm{It}$ is interesting to observe, nevertheless, that general education, in partial eclipse at the undergraduate level, is beginning to make inroads at the graduate level. At Chicago, for example, a number of those faculty members who were active in the "Old College" as professors or students now serve on one or

7 Wolff, op. cit., pp. 147-48.

70 Joseph R. Gusfield, "General Education as a Career: A Sociological Analysis," Journal of General Education, X (January 1957), 38.

" See Joseph Gusfield and David Riesman, "Faculty Culture and Academic Careers: Some Sources of Innovation in Higher Education," Sociology of Education, XXXVII (Summer 1964), 305. 
more of the three interdisciplinary committees which award doctorates, one might almost say, in general educationthe Committee on Social Thought (originally founded in the early 1940's with Hutchins' active assistance, as the Committee on Interrelation), the Committee on the Analysis of Ideas and the Study of Methods, and the Committee on the History of Culture. The program of the Committee on the Analysis of Ideas and the Study of Methods resembles, in its objectives, the "Old College" course on Observation, Interpretation, and Integration; indeed, Richard McKeon, who taught that course, is the chairman of the committee. The graduate program in the History of Ideas at Brandeis University parallels the Chicago efforts in its attempt "to examine the interrelations of ideas in the various disciplines, the interconnections between theoretical and practical activities, and the reciprocal influence of ideas and historical events."78 The existence of these programs at the graduate level and the anticipated development of similar activities in other universities would seem to augur well for undergraduate programs of general education which need a steady supply of generalists.

Two problems which are likely to bear upon efforts to reorganize knowledge are: (1) investigations into the nature of the relationship between the observer and what is observed in the natural and social sciences; and (2) investigations into the correlation of concepts, as mental constructs, with their neurophysiological bases. With regard to the former, it can be suggested that the mechanism which science has developed to cope with uncertainty in the subatomic realm -that is to say, the forecasting of averages in ensembles-will play an increasing role in the social sciences whose objects of inquiry-individuals, individuals

is See the Bulletin of the Graduate School of Arts and Sciences, Brandeis University, 1965/196; (Waltham, Mass.: Brandeis Univ., 1965), pp. 108-18. in groups, and groups themselves-are also subject to behavioral deflection by the very act of observation. ${ }^{79}$ It is as if the grossest observations of the social scientist affect those macro systems which he investigates in the same way that the finite quanta of energy which physicists employ when studying the microcosmos affect the behavior of elementary particles. The observations of both the social scientists and the physicist are, in deterministic perspective, what Henry Margenau calls "epistemologically destructive." ${ }^{0}$ In his judgment, the statistical devices which explain subatomic behavior in probabilistic terms can also be applied to the kind of free behavior observed with respect to social groups. ${ }^{81}$ The problem of predicting individual human action, even on a probabilistic basis, poses far more difficulty than the statistical explanations of social group behavior. While the suicide rate for a sizable population can be predicted within the limits of probability, a variety of factors carry adequate predictions of individual human action well beyond the capacity of existing statistical tools. ${ }^{82}$ Nevertheless, science and social

\footnotetext{
${ }^{70}$ Margenau, op. cit., pp. 54-55. The analogue in the social sciences of Heisenberg's principle of uncertainty (or indeterminacy) in physics is the "Hawthorne Effect." In the late 1930's, investigators at the Hawthorne Plant of the Western Electric Company noted substantial variations in output during those periods when they were observing the production workers. Like the physicist dealing with elementary particles, the social scientist often encounters situations in which he can neither exactly know the present state of a system nor the precise nature of the correlation or causal relationship between the existing state of affairs and some future state of a system. The criteria for demonstrating determinism are to be found in Caws, op. cit., pp. 300-301.

${ }^{\text {so }}$ Margenau, op. cit., pp. 62-63. Karl Popper sees the solution (or better, resolution) of such fundamental epistemological problems in Alfred Tarski's theory of objective truth as synonymous with simple compliance with the facts. See his discussion of Tarski's thesis in Conjectures and Refutations: The Growth of Scientific Knowledge (London: Routledge and Kegan Paul, 1963), pp. 223-26.

${ }_{81}$ Margenau, op. cit., pp. 93-97.

82 Caws, op. cit., p. 303 . One reason why man's knowledge of the nature of nonhuman organic and inorganic entities may always exceed that which he has of himself is due to his anti-life or anti-nature posture. Such a posture has its origin in the very process of hominization and sets man epistemologically at a distance from nonhuman nature, thus providing,
} 
science appear to share a statistical methodology which permits them to fathom, in like fashion, the complexity of social and subatomic life.

Another problem which has implications for the organization of knowledge is the relationship between conventional or nonexperimental epistemology and the newer empirical epistemology which is based on a variety of disciplines including neurophysiology and information theory. Needless to say, physiological theories of knowing have a much briefer history than their speculative counterparts. ${ }^{83}$ The following remarks by some Oxford dons, attributable, it is my understanding, to Ralph Gerard, exemplify the difficulty of precisely correlating concepts with the structures and processes in the central nervous system on which they are based. The dons are reputed to have seen a group of women walking just ahead and obviously plying the trade.

Said one, "I see ahead of us a jam of tarts." The second picked it up, "I should describe them as a volume of Trollop's."

The third rose to the occasion, "To me they are a flourish of strumpets."

The fourth was still abreast of the punning and said, "No, I think we have an anthology of prose."

\section{The field of experimental epistemology}

it is suspected, a kind of built-in objectivity vis-à-vis such phenomena. Such objectivity is probably denied the infant and young child who perceives a basic continuity between man and nonhuman life prior to that time when the limits of his ego and nonego become more sharply delimited. See Harold D. Lasswell, "The Major Trends in World Politics," in Harold D. Lasswell and Harlan Cleveland (eds.), The Ethic of Power: The Interplay of Religion, Philosophy, and Politics (New York: Harper, 1962), p. 349.

$\$$ Warren S. McCulloch, "A Historical Introduction to the Postulational Foundations of Experimental Epistemology," in F. S. C. Northrop and Helen H. Livingston (eds.), Cross-Cultural Understanding: Epistemology in Anthropology (New York: Harper, 1964), p. 183. Boulding has suggested that there may be a "Heisenberg principle" at work which will prevent investigators from knowing in any deterministic kind of way the nature of the physiological structures corresponding to man's knowledge structures. See Boulding, op. cit., pp. 16-17. Whether this is so remains to be seen as Koch in Wann (ed.), op. cit., pp. 4-5, has suggested. received great impetus when Warren McCulloch first enunciated his postulate regarding the circular configuration of sets of neurons in the human nervous system. It is important to realize that for McCulloch the notion of neuron circuits was abstract and postulated and that within the bounds of his theory vacuum tubes or transistors might have served just as well as neurons. In this theory, circularly arranged neurons are set off through the firing of one neuron along the circuit which is in some way linked to a stimulus coming in over the sensory organs. After the initial firing, these neural rings continue to reverberate in much the same way that a circle of dominoes might continue to reverberate if the domino which originally set off the circuit by falling were stood up, along with the other fallen dominoes, before the reverberation had completed its circuit and reached again its starting point. In a neural circuit the recovery, or metabolic process in the individual neuron, must take less time than a complete reverberation of the circuit or the circuit will cease to reverberate. There are many such neural circuits present in the human nervous system, each capable, it is hypothesized, of trapping universals (like shape regardless of size) from environmental stimuli. It seems possible, moreover, that neural circuits of trapped impulses corresponding to environmental stimuli may be permuted and associated in the cortex and thus employed to define other, more fully abstract notions which will reverberate around their own neural circuits. Thus it is possible to postulate a cortical heirarchy containing neural circuits corresponding to philosophical concepts as well as inductive facts. ${ }^{84}$ The source of concepts which are postulated by the imagination or intellect, that is to say-

\footnotetext{
4 F. S. C. Northrop, The Complexity of LegalEthical Experience: Studies in the Method of Normative Subjects (Boston: Little, Brown, 1959), pp. 109-
} 10. 
not given in immediate sense experience, is a puzzle of far greater complexity. It is my understanding that experimental epistemologists know considerably less about the neurophysiological foundations of imagined or intellected concepts than about those of concepts which have, at some point in time, been abstracted from reality by a process of induction. With regard to the latter, it is believed that the regenerative activity in a neural circuit permits a trapped stimulus to reverberate initially for about half an hour. At the end of that time, if the reverberation has not been interrupted, the neurons along the circuit seem to contain an increased amount of ribonucleic acid and protein synthesis has gotten under way. This activity results in local changes in the electrical characteristics of the neurons themselves and leads, in some way, to the anatomical embodiment of the impulse trapped in the reverberating circuit. $^{85}$ Child psychologists see this ability to trap universals as developing in humans between the ages of three and eleven. From the third year on, for instance, children develop the capacity of "conservation," that is to say, they are able to conserve the notion of circularity despite changes in the area or color or background of the circles presented to them. Sometimes after developing the capacity to conserve, children begin to classify objects according to their configuration and to develop the power of seriation-that is to say, the ability to order objects hierarchically in terms of the increasing or decreasing value of some attribute. The principles of classification and hierarchical ordering (or grouping and seriation) are, in the judgment of Jean Piaget and his colleagues in genetic psychology

${ }^{85}$ See McCulloch in Northrop and Livingston (eds.), op. cit., pp. 191-92. Reverberation may also result in lowered resistance along a given circuit which can be easily reactivated by fresh perceptual stimulus (that is to say, recognition after long memory) or even by internal stimulus in the absence of perception (that is to say, in response to representation). at the University of Geneva, the basis for concept formation in adult life. ${ }^{86}$

The experimental epistemology which has developed up to now makes no claim to full physiological realism. ${ }^{87}$ But the theoretical model developed by $\mathrm{McCul}$ loch does suggest that man does not bring a tabula rasa or Lockean blank tablet to the data provided him by his senses. And the notion of circular rather than linear ordering of neurons provides excellent support for this suggestion. In terms of concept formation and retention, there is a world of difference between closed loops and linear trains. The McCulloch theory also accords with Dean Wooldridge's hypothesis of attention-focusing mechanisms which not only select out those circuits which will be permitted to reverberate for the full half hour but also those which will be embodied in the brain over the long term..$^{88}$ At all events, it seems that man brings to his experience on an a priori structure rooted in the nervous system, through

\footnotetext{
86 Michael Wallach has described the child's ability to conserve as "the understanding that no change has occurred regarding one or more aspects of an object or a relationship, despite change in other perceivable features." See his "Research on Children's Thinking," in Harold W. Stevenson (ed.), Child Psychology (The Sixty-second Yearbook of the National Society for the Study of Education [Chicago: Univ. of Chicago Pr., 1963]), p. 246 , also pp. $255,259,262,264$.

st Neurophysiological models of brain functioning can still be constructed, for, as McCulloch has put it, with the birth of cybernetics "teleology had its proper mechanistic base in engineering and biology." See McCulloch, in Northrop, op. cit., pp 185-86.

${ }^{83}$ Dean Wooldridge has hypothesized a three-stage concept of memory: (1) The Sensory Input Stage (in which the datum of the senses is sorted for special attention and reinforcement by a focusing mechanism); (2) The Medium Term Memory Stage (corresponding to McCulloch's notion of reverberating circuits of neurons); and (3) The Permanent Memory Stage (in which a reverberating neural circuit is incorporated into the memory system, it is suggested, via some kind of change in the efficiency of the synapses which connect the neurons in the circuit involved in the final storage of a memory trace. W. Ritchie Russell has proposed that the low resistance neural circuits where a memory has already been established are constantly reinforced by the action of circuits which have been randomly generated through the occasional firing of neurons in the absence of some external stimulus. This means that the memory traces which have been stored in the storage mechanism of the brain grow progressively stronger over time through the action of these randomly generated circuits. See Dean Wooldridge, The Machinery of the Brain (New York: McGrawHill, 1964).
} 
which incoming data is interpreted in much the same way that a program instructs a computer to perform certain operations on input data. This suggests further that the brain has a mechanical causality which is teleological in nature, that is to say, that the brain manipulates incoming information in terms of a hierarchical complex of goals and subgoals. Donald MacKay has speculated that the terms in which a given individual perceives some aspect of the empirical world will depend, in the final analysis, on the extent to which such a perception is supportive, nonsupportive, or capable of modifying the individual's hierarchy of goals. In the "internal matching" of stimulus and goal complex, the stimulus which generates no response in the goal apparatus will simply not be perceived or conceived in any meaningful way. These goal complexes, originally developed in response to what MacKay calls "patterns of demand" which the world presents to the organism, serve as organizing systems. Complex structures are thus perceived in terms of the internal organizers which previous goal seeking has developed in the individual. It is possible, MacKay suggests, for individuals to have "epistemological blind spots" in which no complex of organizers defined by the individual's goal complex corresponds to incoming sensory information. In other words, conceptual innovation at certain levels is out of the question for some individuals who-in order to react meaningfully to certain concepts-would need to demolish and reconstruct their goal complexes, a task of great formidability. ${ }^{89}$ Herbert Simon and Allen Newell have sought to understand the operation of the organizers specified by goal complexes independently of the biology of the brain, by inferring from the behavioral response to a known input the kind of information processing that took place in the brain. In this way,

so See Donald M. MacKay, "Communication and Meaning-A Functional Approach," in Northrop and Livingston (eds.), op. cit., pp. 168-70. a computer program can be developed which will permit a simulation of the problem-solving processes in a sophomore's mind. ${ }^{90}$

Related to ongoing research in the area of human cognition is the recent work of the experimental psychologist, J. C. R. Licklider, on the design of an advanced system which would intervene between a given corpus of recorded information and the cognitive structure or map which an individual seeking knowledge brings with him to the interaction with a body of knowledge. The thesis seems to be that it is easier to organize information for transmission to individuals with unique cognitive structures than to attempt to reorient cognitive structures to a statically organized body of information. Such a system, called by Licklider a procognitive system, would permit a process of negotiation between the cognitive structure of the information seeker, as target, and a body of information with a given initial organization. In all likelihood, such a system would consist of some linkage between a computer with a very large random access storage capacity ${ }^{91}$ and a teaching machine and, of course, the sources of knowledge generation. ${ }^{92}$ Unlike conventional library and information systems, the units of discourse in this design would be conceptual and factual knowledge, not the physical artifacts or documents within whose bounds knowledge is constrained and arbitrarily organized only in terms of the cognitive system of the author and those who are on the

\footnotetext{
${ }^{90}$ Herbert A. Simon and Allen Newell, "Information Processing in Computer and Man," American Scientist, LII (1964), 281-82.

n Serial access computer memories have storage capacities which are roughly one thousand times greater than random access memories. In terms of access speed, however, random access memories are about ten thousand times faster than serial access memories. as The console of the procognitive system would, therefore, have buttons labeled respectively "Where am I?" and "What should I do next?" These buttons would enable the knowledge seeker to negotiate a rapprochement with the body of recorded knowledge through the conceptual good offices of the intermediate procognitive system itself. See J. C. R. Licklider, Libraries of the Future (Cambridge: MIT Press, 1965), p. 127.
} 
same wavelength with him. ${ }^{93}$ Defining solid information as that which excludes popularizations, ephemera, and unqualified contributions, Licklider has predicted that the increasing size of high speed random access computer memories by 1985 will permit, despite prodigious growth in the body of recorded knowledge, a procognitive system user to interact simultaneously with the solid literature of a subfield of science and technology, with a scientific or technical discipline by 1988 or 1989 , and with all of science and technology by $1996 .{ }^{94}$ This assumes, of course, that an adequate mechanism for knowledge organization can be developed with sufficient versatility by those dates. It is interesting to note, however, that a subcommittee of the Federal Council for Science and

\footnotetext{
as Compare, for example, the imaginative speculations of Licklider, ibid., pp. 21-69, with the less sophisticated extrapolations of John Kemeny in his " $\mathrm{A} \mathrm{Li-}$ brary for 2000 A.D.", in Martin Greenberger (ed.), Management and the Computer of the Future (New York: MIT Press and Wiley, 1962), pp. 134-177, where the library is seen as continuing to contain mainly physical artifacts (like books and periodicals); where the library is conventionally classified; and where information access is assured, by and large, through refinements in presently existing technology. It certainly can be speculated that scientists operating on the leading edges of theoretical research prefer informal or nonbibliographical channels of communication for reasons other than the time lag between the germination of an idea for an article in the mind of a scholar and the formal entry into the public domain of science via the published article ultimately embodying the idea. The feedback incorporated in interpersonal interaction (whether orally or through correspondence) cannot be duplicated in the interaction between a scholar and the formal publications of a colleague. Scholars are likely, for example, to be more speculative, to risk more, and to be less circumspect with regard to the dimensions of their thought in an informal situation. That is why there is a need to formalize the informal means of communication without, at the same time, eliminating the informal which makes these channels so viable. Russel Ackoff has in mind, as I understand it, a project which would formalize certain aspects of the intellectual interaction in the "invisible colleges" identified by Derek DeS. Price in his Little Science, Big Science (New York: Columbia Univ. Pr., 1963). See also the discussions of informal communication in William D. Garvey and Belver C. Griffith, "Informal Channels of Communication in the Behavioral Sciences: Their Relevance in the Structuring of Formal or Bibliographic Communication," in Bergen (ed.), op. cit. and Richard H. Orr and Associates, "Communication Problems in Biomedical Research: Report of a Study," Proceedings of the Federation of American Societies for Experimental Biology, XXIII (September-October 1964), 1117-32.

"s See Licklider, op. cit., pp. 13-20.
}

Technology, known as the Committee on Scientific and Technical Information, is planning a national information system which embodies two distinct but related subsystems. There is to be a library subsystem (consisting of a complex of libraries) which is document-oriented, and an information subsystem (directed to the evaluation, storage, and retrieval of information per se). The library system would satisfy the requirements of those who seek humanistic and some forms of social science knowledge and who are interested in nonscientific ideas. The information system would provide natural scientists and most social scientists with conceptual and factual information. ${ }^{95}$ Another development of interest in the organization of knowledge (as recorded knowledge) is the SYNTOL (Syntagmatic Organization Language), a general system developed by Jean Gardin in France between 1960 and 1962 and currently applied to a set of brief abstracts in the field of cultural anthropology. In this system, there is a paradigmatic organization in which relations are established a priori between index terms which have been developed out of a general surveillance of the fields involved, but which are not derived from any specific document. The strategy employed in developing the paradigmatic dimension of the system is not unlike that used in constructing an a priori classification scheme. The syntagmatic dimension of the system, unlike the paradigmatic, is a posteriori-that is to say, based on relations between terms which have actually been found in the documents of the fields involved. ${ }^{96}$ The

95 William T. Knox, "The Changing Role of Libraries," ALA Bulletin, LIX (September 1965), 720, 724 .

90 As I understand it, the syntagmatic dimension of SYNTOL bears at least some resemblance to the concept of associative indexing suggested by Lauren Doyle in his "Semantic Road Maps for Literature Searchers," Journal of the Association for Computing Machinery, VIII (1961), 553-78. It also seems related to the concept of faceted classification favored by the Classification Research Group in England and by the Indian classificationist Ranganathan. 
SYNTOL is, therefore, both precoordinate and postcoordinate in character. My understanding of this system is limited and imperfect, but it is supposed to be capable of concept coordination. ${ }^{97}$ In discussing the system, Victor Yngve has foreseen the possibility of revising, reorganizing, and updating the paradigmatic component on the basis of the ongoing development of the syntagmatic component, linked as it is with the ongoing development of knowledge as incorporated in actual documents. Drawing an analogy between the paradigmatic dimension and innate knowledge and the syntagmatic dimension and acquired knowledge, he suggests that "one can imagine a learning method by which syntagma that are collected-acquired from new documents, in this case document representations or surrogateswould be abstractly incorporated in the paradigmatic, innate structure, subject to certain conditions of acceptability. In this way the 'culture' of the computer would continually be extended, reorganized, updated, under the impact of the recent scientific data found in the newly processed literature." 98 This conversion of syntagmas into paradigms finds its analogue, it appears, in the modification of empirically based concepts on the basis of new experimental evidence, or the modification of very general concepts on the basis of new found correlations among its components-the empirically based theories. Obviously, systems like the procognitive and the SYNTOL are ready-made for the involvement of general systems theory. General system principles could serve as organizers in the procognitive system and as specifiers of knowledge relationships in the

\footnotetext{
$"$ For a basic elaboration see Susan Artandi, "SYNTOL-A New System for the Organization of Information," Library Resources and Technical Services, IX (Fall 1965), 473-75, 477. For a more extensive treatment, see J. C. Gardin, SYNTOL (New Brunswick, N.J.: Graduate School of Library Service, Rutgers-The State University, 1965).

os Gardin, op. cit., pp. 95-96.
}

paradigmatic component of the SYNTOL. These possibilities will be discussed more fully later in the paper.

Prior to discussing the implications of general systems theory for librarianship and higher education in any great detail, it might be well to devote some space to a general consideration of models, theories , and concepts. A brief treatment should suffice here. There are, of course, many different kinds of reasoning: the mathematical or logical (with its internal aesthetic and independence of empirical reference); the scientific (which also may be deductive, but which makes empirical referents imperative); and the philosophical (which may also be deductive, but which is concerned with ultimate meanings and is frequently prescriptive or normative in character). ${ }^{99}$ Robert Morton, the advocate of "middle range" theory in sociology, has identified the functions of broad theory or paradigms as: (1) notational (including economy in the logical incorporation of lower-level theories); (2) logical (in the sense that they prohibit the incorporation of logically irresponsible hypotheses); (3) cumulative (in their support of knowledge cumulation); (4) heuristic (in their guidance of the definition, investigation, and solution of problems); and (5) organizational (in their ability to codify knowledge). ${ }^{100}$ An excellent definition of theory is that recently formulated by Karl Deutsch and Leroy Rieselbach. They write:

To the Greeks, theoria meant the passionate contemplation of reality; to the modern scientist, theory means an abstract, symbolic image or model of relevant aspects of reality - a model which may or may not be capable of being imagined in visual terms, but which in any case permits the

${ }^{20}$ See Belth, op. cit., pp. 8-11.

${ }^{100}$ Robert K. Merton, Social Theory and Social Structure (rev. and enl. ed.; Glencoe, Illinois: Free Press, 1957), pp. 5-6, 14-15. See also Belth's delineation of the functions of theory, in Belth, op. cit., pp. 29-30. 
orderly retention and recall of relevant memories from the past, and the forming of relevant and, as far as possible, dependable expectations for the future. Every theory is then in principle an engine for the selection of information as well as for its storage and retrieval, and for the making of predictions. If it is an open theory, rather than a closed one, it will also be an instrument to start or extend the search for new information, and for the dissociation and recombination of old and new information into patterns by means of which the original theory itself may be extended, transformed, or replaced by a new one. And, of course, if it is a scientific theory, it will be susceptible to testing by operational evidence, that is, by evidence obtained by standardized and impersonally reproducible procedures.

The foregoing, it seems, ${ }^{101}$ summarizes in extremely cogent terms the manifold functions of theory.

Theory is often, as Deutsch and Rieselbach indicate, cast into the form of a model. ${ }^{102}$ Abraham Kaplan has described models of all kinds as the "embodiment of a structural analogy" in which the elements and their relations in the model are such that something may be learned about the system to which the model is seen to correspond. ${ }^{103}$ Verbal models, which seek to explain the unfamiliar metaphorically in terms of the familiar, pervade even day-to-day human intercourse. Such attempts at horizontal ex-

\footnotetext{
${ }^{101}$ Karl W. Deutsch and Leroy N. Rieselbach, "Recent Trends in Political Theory and Political Philosophy," Annals of the American Academy of Political and Social Science, CCCLX (July 1965), 140. See also Karl W. Deutsch The Nerves of Government: Models of Political Communication and Control (New York: Free Press of Glencoe, 1963), pp. 6-8.

${ }_{102}$ Abraham Kaplan has argued that not all theories are models since "the theory states that the subject matter has a certain structure, but the theory does not therefore necessarily exhibit the structure itself." See his The Conduct of Inquiry: Methodology for Behavioral Science (San Francisco: Chandler, 1964), pp. 264-65. See also Belth, op. cit., pp. 30-31, 179-80.

${ }_{100}$ In very broad terms, system $\mathrm{X}$ is a model of system $\mathrm{Y}$ if by using $\mathrm{X}$ one can learn more about the structure and function of $\mathrm{Y}$ without directing any special attention to direct or indirect causal relationships between the two systems. Kaplan, op. cit., pp. 263, 266-67. See also Belth, op. cit., p. 88.
}

planation are, however relatively ineffectual at those dimensions where familiar analogues no longer exist, for example, at $10^{-13}$ centimeters or a billion light years. It is at these extremities of size and distance that mathematical models carry man out of his anthropomorphic dilemma. ${ }^{104}$ Good models often permit the identification of those components of empirical reality which it is most important for man to measure. Of the several functions performed by theories and models, the most important from a general systems point of view are probably the organizational, the explanatory and the heuristic-predictive. It is in these functions particularly that theories and models serve as intellectual machine tools. ${ }^{105}$ The interaction of the organizational and heuristic functions of models and theories have been described in feedback terms-the organizing power is heuristically suggestive and it expands as the effects of problem solving pay off in new insights regarding the knowledge which is organized by the model or theory. ${ }^{106}$

Having devoted some space to the treatment of models and theories, it may be worthwhile at this point to consider

104 Warren Weaver, "Scientific Explanation," Science, CXLIII (March 1964), 1297-1300. Also Belth, op. cit., p. 89. Herbert Simon has argued additionally that mathematical models, by virtue of their ease of manipulation, provide their employers with certain psychological advantages. See his "Models: Their Uses and Limitations," in Leonard White (ed.) The State of the Social Sciences. (Chicago: Univ. of Chicago Pr., 1956), pp. 71-72.

${ }^{105}$ Karl Deutsch uses the image of the safecracker's kit, filled with the tools of his trade, to suggest the importance of the intellectual's possessing an array of theories and models for the organization of reality, or intellectual safecracking. See his "Higher Education ..." in Bryson et al., op. cit., p. 133. In physiology, the concepts of organ and organ function served as heuristic devices, in that prior to the employment of these concepts there was little really certain knowledge about the structure and function of organs in a complex organism. See Joseph J. Schwab, "The Concept of the Structure of a Discipline," Educational Record, XLIII (July 1962), 198. See also Nash, op. cit., p. 369 .

${ }^{100}$ For an excellent treatment of this phenomenon, see Nash, op. cit., pp. 87-88, 248-49, 269. Gyorgy Polya's notion of the science of heuristics is discussed in Polanyi, op. cit., pp. 127-128. 
general systems theory in its relationship to what has gone before. Many readers are undoubtedly familiar with the general outline of the development of the systems or holistic approach from the excellent discussion contained in Ludwig von Bertalanffy's book, The Problems of Life: An Evaluation of Modern Biological and Scientific Thought; ${ }^{107}$ with the activities of the Committee on the Behavioral Sciences at the University of Chicago through 1954; with the subsequent work done at the Mental Health Research Institute at the University of Michigan; and with the systems research conducted at a number of institutions, often under the title of operations research. The idea of general systems theory, as formulated by von Bertalanffy, goes back at least to the 1930 's. It is the holism of the systems approach which no doubt appeals to its many adherents. René Dubos has vividly contrasted this approach to reductionism in the following passage:

The reductionist and holistic approaches to human problems are well symbolized, it seems to me, in two beautiful portraits of scientists, one by Franz Hals, the other by Rembrandt. The portrait by Franz Hals is a painting of René Descartes, in the Musée du Louvre. It conveys the clarity and vigor of orthodox science, confident in the power of its analytical method. The intellectual assurance of the experimenter arises from the fact that he has learned to deal with simplified systems, representing selected aspects of the world rather than total reality. The portrait by Rembrandt is an etching in the Philadelphia Museum of Art, depicting a physician who has just seen a sick person. His attitude, at the same time perplexed and reflective symbolizes the bewilderment and awe experienced by any thoughtful scientist coming face to face with the problems of the body and the mind of the throbbing men in direct contact with life as it occurs in nature. Rembrandt's doctor seems hesitant, yet eager

In New York: Harper, 1960. to grasp the real meaning of total experience. ${ }^{108}$

The systems approach has been found useful in so many different domains of inquiry that David Easton recently characterized it as "one of the thunderous concepts of the century." 109 As a unit of discourse, the modern notion of system implies more than did the classical concept of system. It implies that the whole is greater than the sum of its parts. General systems theory of course is based on the belief that system elements and behavior is controlled by processes which, if not tightly analogous -that is to say, homologous-are at least in some way isomorphic.

One of the major difficulties with the systems approach, it would appear, however, is the real danger it poses for committing what has been called the "fallacy of misplaced concreteness," that is to say, the confusion of invisible, theoretical entities with concrete, observable ones. ${ }^{110}$ This raises an important question: Are systems, viewed as sets of physical or conceptual entities whose attributes have some kind of relationship to one another, really present in nature or is the notion of system simply an artificial construct which is imposed on nature to aid human understanding? The answers to this question vary depending on whom one consults. In the judgment of A. D. Hall, system seems to imply an artificial construct since one somewhat arbitrarily determines-on the basis of one's interests and the problem at hand-which elements are to be included in a system, which elements are to be excluded from it, and, finally, which intrasystem and system-environment relationships are going to be observed. The set of physical or conceptual entities which comprises

10 René Dubos, "Logic and Choice in Science," Proceedings of the American Philosophical Society, CVI (October 1963), 374.

100 David Easton, A Framework of Political Analysis (Englewood Cliffs, N.J.: Prentice-Hall, 1965), pp. 24-25.

${ }^{110}$ Caws, op. cit., p. 285. 
a system, therefore, is left largely to the observer. ${ }^{111}$ On the other hand, Michael Polanyi has written: "The most daring feats of originality are still subject to this law: they must be performed on the assumption that they originate nothing, but merely reveal what is there." ${ }^{112}$ The British anthropoligist, A. R. RadcliffeBrown, arguing from what he describes as the Aristotelean-Ephesian concept of natural law, regards systems as imminent in nature, that is to say, there from the beginning of time. He reaches this conclusion after considering and rejecting the Newtonian (law as imposed on reality by God); positivist (law as a statement of something that has been observed); and pragmatic (law as a generalization that works in the world) concepts of law. ${ }^{113}$ Within this perspective, therefore, systems can be isolated from one another, and the observer should be able to distinguish, for example, between a political system and an economic system. The individual disciplines, moreover, can be identified by the classes of systems with which they deal. For Radcliffe-Brown, conceptual systems conformed with the systems of natural reality. ${ }^{114}$ David Easton, on the contrary, objects to the notion of natural systems and presents strong arguments to buttress his view that system is a construct imposed upon nature as a matter of theoretical convenience. Looking at systems from the viewpoint of a behavioral scientist, Easton admits that in the physical and biological sciences systems may seem quite natural in that they are generally coherent and possess what seem to be clearly defined boundaries. Social systems, however, seem much less naturally

\footnotetext{
11 See A. D. Hall, A Methodology for Systems Engineering (Princeton, N.J.: Van Nostrand, 1962), pp. 60-61.

112 Polanyi, op. cit., p. 130.

113 A. R. Radcliffe-Brown, A Natural Science of Society (Glencoe, III.: Free Press of Glencoe and Falcon's Wing Press, 1957), pp. 13-14 and 19-20.

114 Ibid., pp. 23-24. See also Easton, op. cit., p. 28.
}

coherent and bounded. Even biological systems, claims Easton, have boundaries which are something less than completely defined. Cytologists, it seems, have difficulty during certain parts of analysis in differentiating the epidermal cells from the air which surrounds them. In his view of systems, the political system, as construct, is defined by institutions which "are more or less directly related to the authoritative allocation of values for a society."115 Institutions which cannot be included within the domain of this definition constitute the parameters or environmental givens of the political system. Systems as constructs are, therefore, neither true nor false, but are simply more or less useful or contributive to our understanding of the phenomena under investigation. There are, of course, undertones of pragmatism in a view which orients to reality on the basis of utility, but it avoids controversy over what is really a system, a difficulty which would be inevitable in the natural systems point of view. ${ }^{116} \mathrm{It}$ seems possible to relate both views of system-the natural and the artificially constructed-to Whitehead's metaphysics of organism in which all entities, human and nonhuman, are social and possess the quality of sympathy for one another. ${ }^{117}$ The difficulty set out above is probably why James Miller, in his recent report on behavior in living systems, was careful to distinguish conceptual, abstracted, and concrete systems. Differentiating abstracted systems from conceptual systems by suggesting that the former are more likely to have empirically determined components, Miller argues that the unification of the sciences would proceed more rapidly if all of the sciences were oriented to either con-

115 Easton, op. cit., pp. 65-66.

116 Ibid., pp. 27-30, 33-34, 44-45, 64-66.

11 See Alfred North Whitehead, "Process and Reality: An Essay in Cosmology," in F. S. C. Northrop and Mason W. Gross (eds.), Alfred North Whitehead: An Anthology (New York: Macmillan, 1953), pp. 567-84. 
crete or abstracted systems. ${ }^{118}$ Concrete systems, it is important to note, can most generally be ordered hierarchically according to their complexity, an observation not at all startling when one recalls that the world evolved toward complexity from simplicity. ${ }^{119}$

In order to reorganize knowledge for transmission in the educational process, and to develop library systems which are supportive of that reorganization, some decisions must be made about what knowledge is important and what is not. ${ }^{120}$ It is the writer's view that economic structure is all-important and that, to quote Boulding, "if a single theoretical principle can be shown to apply over a wide area of the empirical world, this is economy in the learning process." ${ }^{121}$ The economy provided higher education by such metatheories is important to con-

${ }^{118}$ James G. Miller, "Living Systems: Basic Concepts," Behavioral Science, X (October 1965), 202, 204,207 . Easton has been inclined to make a similar differentiation between behaving systems and symbolic systems, op. cit., p. 26. Parsons has distinguished theoretical (what Miller might be inclined to call abstracted) systems from empirical systems. He writes: "Methodologically, one must distinguish a theoretical system, which is a complex of assumptions, concepts, and propositions having both logical integration and empirical reference, from an empirical system which is a set of phenomena in the observable world that can be discovered and analyzed with a theoretical system," Talcott Parsons, "Social Systems and Subsystems," in David L. Sills (ed.), International Encyclopedia of the Social Sciences (New York: Free Press of Glencoe; in press). The citation is to p. 1 of the mimeographed version of the article.

11 Simon reasons that our ability to hierarchically order empirical systems is based on the fact of the dynamies of intrasystem interaction. See his "The Architecture of Complexity," Proceedings of the American Philosophical Society, CVI (December 1962), 477, 481-82. See also Kenneth Boulding, "General Systems Theory-The Skeleton of Science," General Systems, I (1956), 13-16, and Charles Morris, Signification and Significance: A Study of the Relations of Signs and Values (Cambridge: MIT Press, 1964), pp. 20-21.

${ }^{120}$ This is a principle, suggests Richard McKeon, of which "the philosophers of Greece, the summists of the thirteenth century, the universal men of the Renaissance, and the polymaths of the eighteenth century" were well aware. Se McKeon in Cohen, op. cit., p. 174.

121 Boulding, The Image: Knowledge in Life and Society, pp. 162-63. Alvin Weinberg has expressed his concern that university science, and the elementary secondary school science curricula which university scientists are helping to shape, overemphasizes the specialized search activities of pure science at the expense of the important and legitimate scientific function of codification. See his "But Is the Teacher also a Citizen?" Science, CXLIX (August 1965), 603-604. template in view of the complaints about the length of the typical undergraduate, graduate, and professional programs and what, in my judgment, are the pseudocomplaints of faculty members about "having too much material to cover" and the "explosion of knowledge."122 The organization of knowledge is the key to the problem and it rests, by and large, on the "set of related definitions, assumptions, and propositions which deal with reality as an integrated hierarchy of matter and energy."123 For a general systems theory to develop fully, great care must be exercised in identifying isomorphic system principles. And analogies must be carefully drawn between theoretical systems which have empirical linkages. ${ }^{124}$ It is one of the great beauties of general systems theory that it is free to identify isomorphism in the principles which are operative in social, as well as physical and biological systems. ${ }^{125}$ The randomness, uncertainty, and organized com-

${ }^{222}$ It is my intuitive notion that the phrase "explosion of knowledge" is in some respects a myth. To be sure, there is a gradual expansion of basic or fundamental theoretical knowledge, but there is by no means an explosion of deductively fecund conceptual systems. What there seems to be is a publication explosion reflecting the exponential increase in knowledge which is crudely empirical or of low theoretical order.

${ }^{123}$ Miller, "Living Systems . . . ," op. cit., p. 193.

1av Kenneth Boulding has reminded us that analogies are only as good as the empirical linkages to the theoretical systems from which they are drawn. See his "General Systems as a Point of View," in Mihajlo Mesarovic (ed.), Views on General Systems Theory (New York: Wiley, 1964), p. 32.

125 Early attempts at identifying general theories, based on the isomorphism of lower order generalization, led, for example, to the observation that the exponential law of mathematics applied to a range of behaviors from radioactive decay to the death rate of bacteria under certain conditions to the rate of decrease in human and animal populations where the mortality rate exceeds the birth rate to (it might be added) the growth rate of the literature of science. Now James Miller has developed some one hundred and sixty-five different hypotheses which are crosslevel in the sense that they apply to the behavior of living systems at different levels of complexity. It is interesting to note that in the process of developing these hypotheses, Miller also identified discontinuities like longevity, size, and diffusion. He has employed matter, energy, and information as his fundamental analytical concepts. See his "Living Systems: Basic Concepts," op. cit., pp. 193, 216; his "Living Systems: Cross-Level Hypotheses," Behavioral Science, X (October 1965), 380-411; and, finally, his "Living Systems: Structure and Process," Behavioral Science, X (October 1965), 337-79. 
plexity present in all three kinds of systems render them open to the application of mathematical methods which were unnecessary in classical, mechanistic science. ${ }^{126}$ In the process of identifying metaprinciples, general systems theory can be said to be combatting entropy at a very high level. The operations of imagination, correlation, and systematic thought which go into the identification of such general theories of systems result, it has been suggested, in the creation of new information or negative entropy. Therefore, the "form" in the word information is precisely what it suggests, that is to say, formative and structural. ${ }^{127}$

What are the prospects for general systems theory as a curricular integrating principle in undergraduate, and perhaps even graduate level, general education? Boulding already teaches a course entitled "General Systems" to honor seniors at the University of Michigan. In this course, general systems is presented as a point of view rather than a set of techniques. The course objectives seem to follow a perspective on general systems theory shared by Boulding with von Bertalanffy. The course prospectus reads as follows:

The object of this course is to examine the general structure of theoretical systems in many different branches of learning, with a view to establishing relationships among the theories which pertain to various em-

${ }^{126}$ Like finality, equifinality, hierarchical order, and the like. Ludwig von Bertalanffy, Problems of Life: An Evaluation of Modern Biological and Scientific Thought (New York: Harper, 1952), pp. 189-90, 199, 202. Also his, "General Systems Theory-A Critical Review," General Systems, VI (1962), 2.

${ }^{127}$ See Miller, "Living Systems: Basic Concepts," op. cit., p. 194; Henry Quastler, The Emergence of Biological Organization (New Haven, Conn.: Yale Univ. Pr., 1964), pp. 3-4; and Leon Brillouin, Scientific Uncertainty, and Information (New York: Academic Press, 1964), pp. 17-18, 21. For a discussion of the analogy between the linguistic theory of Noam Chomsky and the tiered way in which one can view the structure of science, see Israel Scheffler, The Anatomy of Inquiry: Philosophical Studies in the Theory of Science (New York: Knopf, 1963), p. 7. Of particular interest is the analogy between grammatical units of cross-linguistic relevance (for example, nouns) and the structural terms of science (for example, theory) which have cross-disciplinary application. pirical subject matters. By so doing it is hoped that the student will come to appreciate certain basic unities which underly the universe of knowledge. ${ }^{128}$

In discussing the relationship between systems theory and systems research as two elements in a systems science, Russell Ackoff projects a different point of view. As early as the 1950 's, he expressed his concern about the excessive generalization, operational insignificance, and almost metaphysical point of view which he thought pervaded the systems movement. ${ }^{129}$ Ackoff suggests that where systems theory seeks to identify theories with cross-disciplinary generality, systems research views knowledge as a product of the application of scientific method applied not to phenomena defined by disciplines but to nature viewed holistically, typically in terms of some problem. He would argue that nature does not share the disciplinary organization of universities and that for systems theory to accept such arbitrary divisions is a constraint on its proclaimed holism. For Ackoff the direction of abstraction vis-à-vis system principles is from the complex to the simple, not the reverse. $\mathrm{He}$ is unsettled about the apparent removal of systems theory from the empirical world-a two-stage removal if one considers general systems theories as inductively formulated on the bases of a common principle observed to be operative in a limited set of concrete systems. Therefore, Ackoff argues, more limited theories must be: (1) deduced from the general theories for application to newly identified systems; and (2)

\footnotetext{
123 Prospectus for General Systems (College Honors 498), taught by Kenneth Boulding at the University of Michigan. One scholar has observed that the symbiosis between a professor and undergraduates who lack a full initiation into the ethos of the discipline which he represents can result in a critical examination of the formal foundations of the field, which the symbiotic relationship between a professor and his graduate students or professional colleagues might never elicit. See Richard Wolfgang, "Pure Research, Cultism, and the Undergraduate," Science, CL (December 1965), 1564.

120 Russell L. Ackoff, "Games, Decisions, and Organizations," General Systems, IV (1959), 145.
} 
either validated or invalidated empirically. In sum, however, Ackoff sees good work ongoing in systems theory as well as systems research and seems to suggest that a viable systems science may well require activity in both domains. ${ }^{130}$

It is apparent that both systems theory and systems research can contribute to a systems-oriented undergraduate program of general education. It is of concern in some quarters, however, that general systems theory, especially when it is viewed as a set of postulates or inductively determined theories from which more limited disciplinary theories can be derived and checked against reality, is open to the logical fallacy of affirming the consequent. In the logic of science it can be maintained that a system principle derived from a more general theory of systems is falsified-and with it the general theory of systems-if it does not agree with empirical reality; and it is confirmed, without really confirming the general systems principle, if it agrees with the empirical world. The logic of $(a)$ falsification and $(b)$ confirmation is as follows: (a) If $\mathrm{Y}$, then $\mathrm{X} ; \mathrm{X}$ is not the case, therefore, $\mathrm{Y}$ is not the case and (b) If $\mathrm{Y}$, then $\mathrm{X} ; \mathrm{X}$ is the case, therefore, $\mathrm{Y}$ is the case. However, in the process of confirmation, if $\mathrm{X}$ is the case, $\mathrm{Y}$ may not necessarily be uniquely the case. Therefore, one observes formal validity where there is falsification and formal invalidity where there is confirmation. This is so because the confirmation of $\mathrm{X}$ (a logically derived disciplinary theory which has been deduced from a general theory of systems) does not guarantee that Y (the general theory of systems) is uniquely the case. It is entirely possible, for example, that a different general theory of systems, Z, could also logically give rise to the dis-

\footnotetext{
130 Russell L, Ackoff, "General Systems Theory and Systems Research: Contrasting Conceptions of Systems Science" in Mesarovic (ed.) op. cit., pp. 51-60. This is obviously, as Anatol Rapoport has pointed out, a task for the philosophy of science. See his "Reflections on General Systems Theory," in Mesarovic (ed.) op. cit., p. 171.
}

ciplinary theory $\mathrm{X}$. In brief, if $\mathrm{Y}$ then $\mathrm{X}$; $\mathrm{X}$ is the case; but also $\mathrm{Z}$ then $\mathrm{X} ; \mathrm{X}$ is the case. ${ }^{131}$

The theories and concepts which are employed in systems activity are an interesting lot to observe and compare. ${ }^{132}$ Alfred Kuhn's attempt to unify the knowledge centered in sociology, political science, and economics resulted in the development of concepts like decisions, communications, transactions, organizations, and their combinations. ${ }^{133}$ Ackoff speaks of theories of allocation, queuing, sequencing, routing, replacement, competition, and search and discusses gaming and sequencing in his book, Scientific Method: Optimizing Applied Research Decisions. ${ }^{134}$ The role of mathematics is clear from the frequent mention of Bayesian statistics and Monte Carlo method. Of inventory theory, Ackoff writes:

Within the industrial context, inventory theory can be applied to such diverse phenomena as the acquisition and use of operating capital, the hiring and training of personnel, and the determination of how much and how frequently to acquire productive capacity. It is also applicable to any type of input-output system to which benefits and losses can accrue. For example, the metabolic processes of a living organism can be studied as an inventory process, the operation of a heating system, a computing center, a documentation center, and the natural water system of a geographical region. The inputs, outputs, and systems involved can be of relevance to any and every scientific discipline. The disciplinary

\footnotetext{
ist The foregoing is based on a discussion of portions of F. S. C. Northrop's The Logic of the Sciences and the Humanities, in William P. Ehling, "Toward an Epistemological Integration of Science: A Review of Models Developed in Operations Research, Communications Research, Systems Research, and Cybernetics" (Communications Research Studies in "Epistematics" [Syracuse, N.Y.: Information Science and Communication Management Program, School of Journalism, Newhouse Communications Center, Syracuse Univ., 1965]), pp. 20-22 (Mimeographed).

${ }_{122}$ O. R. Young, "A Survey of General Systems Theory," General Systems, IX (1964), 61. See also Deutsch, "Higher Education . . . ," op. cit., p. 66. ${ }^{123}$ See his The Study of Society: A Unified Approach (Homewood, IIl.: Dorsey, 1963).

124 Ackoff, op. cit., pp. 46-47, 134-35.
} 
characteristics of the relevant variables have no relevance to the theory. ${ }^{135}$

To continue, von Betalanffy has spoken of the exponential law and Gaussian distribution. And O. R. Young, in his overview of general systems theory, develops a taxonomy of concepts employed in systems theory which includes equifinality, state-determined system, goalchanging feedback, overload, and ultrastable system. ${ }^{136}$ In Miller's general systems behavior theory are to be found concepts like passive adaptation, improbability, irregular simplicity, and extremum adaptation. ${ }^{137}$ It is not clear at all times which of these many concepts reflect general system principles and which reflect methodologies or techniques which have very wide application. Most, however, seem to share a mathematical formulation, and some preparation in mathematics would seem to be rather central to a curriculum based on general systems theory.

A number of concerns would have to be reflected in a collegiate curriculum based on general systems theory. A central problem would be the historic role of archetypes and themata in the organization of humanistic and scientific knowledge respectively, and of the possible association of archetypes and themata in some general theory of symbolic structure which would comprehend the humanities as well as the social and natural sciences. Such a theory might profit from the close study of ancient religious systems out of which, Parsons and others have suggested, differentiated secular knowledge sprung. Then too, some sense of the cyclic rise and fall of archetypes and themata could sensitize students to what are likely to be the dominant organizing images during their lifetimes. The paired opposites which

\footnotetext{
135 Ackoff, "General Systems Theory and Systems Research: Contrasting Conceptions of Systems Science," in Mesarovic, op. cit., p. 57.

130 See Young, op. cit., pp. 61-62.

${ }^{137}$ Miller, "Living Systems: Basic Concepts," op. cit., pp. 201,229 .
}

are reflected in archetypes and themata may even suggest a kind of systematic complementarity which would lend credence to Floyd Matson's belief that in the physical principle of complementarity lies "the immense evocative analogy" so pregnant with implication for the social sciences and humanities. ${ }^{138}$ Such a curriculum would have to consider the role of contemporary religion and its relationship to the theoretical structures of other academic disciplines in the Parsonian sense that it "comprises the matrix from which cultural institutions in general have differentiated, and remains the 'master' system in a cybernetic sense." 139 Such a curriculum, as a foundation for the study of general systems principles, should acquaint students with the historical evidence concerning the analogical suggestiveness of models like mechanism, organism, and evolution which diffused outward from their loci of origin to have great impact in other areas of academic endeavor. Such a curriculum might seek to investigate the relationships between themata and archetypes and general system principles themselves. Using Ackoff's distinction, such a curriculum could direct the student's attention to general systems theory in the classroom and to the strategies of systems research during frequent, controlled forays into the world apart from the classroom. It would seem important that the student have some sense of the operational importance (that is to say, the theory in action) of those general systems principles that he encounters in the more formal and abstract part of his education. Such a curriculum might, following the lead of Northrop and Margenau, explore the extent to which viable normative and ethical principles can be derived through the application of sci-

\footnotetext{
${ }^{138}$ See Floyd Matson, The Broken Image: Man, Science, and Society (New York: Braziller, 1964), pp. 243-59, and von Bertalanffy, An Evaluation of Modern Biological and Scientific Thought, op. cit., pp. 176-77.

${ }^{139}$ Parsons, in Sills (ed.) op. cit., p. 26.
} 
entific method. It should also be concerned with the extent to which the normative prescriptions of the world's major religions converge along some very general and abstract principles. In general, such a curriculum should not involve merely the search for general system theories. It should also be concerned with what Whitehead called the unstated, and often unexamined, assumptions which affect the way men view the world. Finally it would seem that in such a curriculum, general systems theory should be used less as a means to unify knowledge than as a mechanism for restructuring knowledge. Of course, the systems point of view would imply breadth of interest and a basic toleration of many different approaches to the development of a systems science.

It is fun to speculate on the kind of library system needed to support such a curriculum. In the first place, it would probably have to be both informationoriented and document-oriented. It would have to be an open system flexible enough to accommodate the shifts in relationship between metatheory and the empirically-based system principles which rise out of individual empirical realms. It would have to have both inductive and deductive capacities-that is to say, when presented with a principle observed to be operative in a specific system, it could provide both the general systems theory comprehending the specific system principle and concrete information regarding the empirical phenomena whose behavior the specific system principle comprehends. When in- terrogated with a general theory of systems, it would provide information on the different systems to which the principle had been found to apply and something about the smaller phenomenal entities which it organizes. ${ }^{140}$ The design and construction of such a library system would, of course, require the collaboration of not only general systems theorists and librarians, but philosophers (especially epistemologists or philosophers of science), mathematicians, computer scientists, classificationists, and operations researchers as well. ${ }^{141}$ And the efficiency and adequacy of such a system would, in all likelihood, be closely related to how well it remained current with the results of ongoing research in the systems sciences and how well its organizing mechanism supported the economy in knowledge transmission stressed in the curriculum itself. ${ }^{142}$

140 This raises the question of the relevance of general systems theory to the development of procognitive systems and to the refinement of the paradigmatio dimension of SYNTOL.

${ }^{101}$ Douglas J. Foskett of the English Classification Research Group strongly urges that systems of classification be developed which take into account advances in scientific thought and the philosophy of science. He has even suggested general systems theory as an area of some possible utility in classification research. See his Classification and Indexing in the Social Sciences (Washington: Butterworths, 1963), pp. 130-31.

112 The English Classification Research Group has for some time considered the theory of integrative levels (or, put a bit differently, hierarchical systems) as a foundation on which to construct general classification schemes. The theory of integrative levels is based on the empirical observation that entities evolve from simplicity toward complexity and on the notion, advanced in the the theory of emergence discussed by Caws, that each successively complex whole is somehow greater than the sum of its parts. See ibid., pp. 132, 134-35, 141, 143; and Douglas J. Foskett, "The Classification Research Group, 1952-1962," in his Science, Humanism, and Libraries (New York: Hafner, 1964), p. 200.

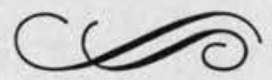

